OPEN ACCESS

Edited by:

Luciana Venturini Rossoni,

University of São Paulo, Brazil

Reviewed by:

Rafael Menezes da Costa University of São Paulo, Brazil Osama F. Harraz,

University of Vermont, United States

${ }^{*}$ Correspondence: Darizy Flávia Silva darizy@gmail.com

Specialty section:

This article was submitted to Vascular Physiology,

a section of the journal

Frontiers in Physiology

Received: 22 December 2020 Accepted: 09 February 2021

Published: 26 February 2021

Citation:

Moraes RA, Webb RC and Silva DF (2021) Vascular Dysfunction in Diabetes and Obesity: Focus on TRP Channels.

Front. Physiol. 12:645109. doi: 10.3389/fphys.2021.645109

\section{Vascular Dysfunction in Diabetes and Obesity: Focus on TRP Channels}

\author{
Raiana dos Anjos Moraes ${ }^{1,2}, R$. Clinton Webb ${ }^{3}$ and Darízy Flávia Silva ${ }^{1,2 *}$ \\ ${ }^{1}$ Laboratory of Cardiovascular Physiology and Pharmacology, Institute of Health Sciences, Federal University of Bahia, \\ Salvador, Brazil, ${ }^{2}$ Postgraduate Course in Biotechnology in Health and Investigative Medicine, Gonçalo Moniz Institute, \\ Oswaldo Cruz Foundation (FIOCRUZ), Salvador, Brazil, ${ }^{3}$ Department of Cell Biology and Anatomy and Cardiovascular \\ Translational Research Center, University of South Carolina, Columbia, SC, United States
}

Transient receptor potential (TRP) superfamily consists of a diverse group of nonselective cation channels that has a wide tissue distribution and is involved in many physiological processes including sensory perception, secretion of hormones, vasoconstriction/vasorelaxation, and cell cycle modulation. In the blood vessels, TRP channels are present in endothelial cells, vascular smooth muscle cells, perivascular adipose tissue (PVAT) and perivascular sensory nerves, and these channels have been implicated in the regulation of vascular tone, vascular cell proliferation, vascular wall permeability and angiogenesis. Additionally, dysfunction of TRP channels is associated with cardiometabolic diseases, such as diabetes and obesity. Unfortunately, the prevalence of diabetes and obesity is rising worldwide, becoming an important public health problems. These conditions have been associated, highlighting that obesity is a risk factor for type 2 diabetes. As well, both cardiometabolic diseases have been linked to a common disorder, vascular dysfunction. In this review, we briefly consider general aspects of TRP channels, and we focus the attention on TRPC (canonical or classical), TRPV (vanilloid), TRPM (melastatin), and TRPML (mucolipin), which were shown to be involved in vascular alterations of diabetes and obesity or are potentially linked to vascular dysfunction. Therefore, elucidation of the functional and molecular mechanisms underlying the role of TRP channels in vascular dysfunction in diabetes and obesity is important for the prevention of vascular complications and end-organ damage, providing a further therapeutic target in the treatment of these metabolic diseases.

Keywords: TRP channels, vascular dysfunction, diabetes, obesity, TRPC, TRPM, TRPML, TRPV

\section{INTRODUCTION}

Diabetes mellitus and obesity are characterized by systemic biochemical and biological abnormalities, including metabolic disturbances, increased oxidative stress (Pandey et al., 2010; Fülöp et al., 2014; D’souza et al., 2016), and elevated circulating levels of inflammatory markers (Panagiotakos et al., 2005; Taha et al., 2019). Obesity is a condition related to disproportionate body weight for height with an excessive accumulation of adipose tissue (González-Muniesa et al., 2017). Moreover, obesity represents the strongest risk factor for type 2 diabetes (Censin et al., 2019), and it is a common comorbidity among type 2 diabetics (Fajarini and Sartika, 2019). On the other hand, diabetes mellitus can be classified into many subtypes, which can be characterized and identified by the presence of hyperglycemia (World Health Organization, 2019). 
Unfortunately, the prevalence of these cardiometabolic disorders has been increasing worldwide (Abarca-Gómez et al., 2017; International Diabetes Federation, 2019). Additionally, it is evident that diabetes and obesity are related with enhanced cardiovascular risk (Ärnlöv et al., 2010; Einarson et al., 2018). Moreover, these cardiometabolic disorders have been linked to a common condition: vascular dysfunction (Schofield et al., 2002; Oltman et al., 2006; Sivitz et al., 2007; Farb et al., 2014). For instance, diabetic and obese individuals can both be affected by an impaired functional endothelium (Steinberg et al., 1996; Doupis et al., 2011) and/or increased vasoconstriction (Hogikyan et al., 1999; Cardillo et al., 2002; Weil et al., 2011; Schinzari et al., 2015), thus leading to vascular complications. Currently, there are a large number of studies that have described the mechanisms of vascular dysfunction, which involve altered transient receptor potential (TRP) channels expression and/or activity, a common event observed in hypertension (Mathar et al., 2010; Alves-Lopes et al., 2020), atherosclerosis (Wei et al., 2013; Zhao et al., 2016), pulmonary hypertension (Yu et al., 2004; Yang et al., 2012) and pulmonary edema (Jian et al., 2008; Thorneloe et al., 2012). Therefore, these channels could provide additional targets for treatment of these vascular diseases. Furthermore, TRP channels are involved in diabetic (Evans et al., 2009; Lu et al., 2014; Monaghan et al., 2015; Zhang et al., 2015) and obesity-related (Zhang et al., 2007; Lee et al., 2015; Sun et al., 2019; Ottolini et al., 2020) diseases. TRP superfamily consists of a diverse group of non-selective cation channels that is divided into six subfamilies in mammals, which are classified as: canonical or classical (TRPC), vanilloid (TRPV), melastatin (TRPM), ankyrin (TRPA), mucolipin (TRPML), and polycystin (TRPP) (Montell, 2005; Ramsey et al., 2006). Additionally, this superfamily is distributed throughout a variety of body tissues, such as blood vessels (Mita et al., 2010; Gao et al., 2020), heart (Andrei et al., 2016), brain (Tóth et al., 2005) and bladder (Yu et al., 2011), among others.

In this context, the correlation between TRP channels, diabetes and obesity have continued to attract growing attention. In this review, we briefly consider general features of TRP channels and focus on TRPC, TRPV, TRPM, and TRPML, which have been shown to be potential involved in the vascular dysfunction of diabetes and obesity.

\section{OVERVIEW ON DIABETES AND OBESITY}

Globally, an estimated 463 million individuals were affected by diabetes in 2019. The International Diabetes Federation estimates that there will be 578 million adults with diabetes by 2030, and 700 million by 2045 . Unfortunately, the global high prevalence of diabetes continues to increase, with no indications of stabilizing (International Diabetes Federation, 2019).

Similarly, the prevalence of obesity is rising in the world. The global number of girls with obesity rose from 5 million in 1975 to 50 million, and the number of boys increased from 6 million in 1975 to 74 million in 2016. As well, the number of adult women with obesity rose from 69 million in 1975 to 390 million, and the number of men grew from 31 million in 1975 to 281 million in 2016 (Abarca-Gómez et al., 2017). In addition, from 2017 to 2018, the prevalence of obesity in the United States was $42.4 \%$, and the prevalence of severe obesity was $9.2 \%$ among adults (Hales et al., 2020). The study by Sonmez et al. (2019) demonstrated a high prevalence of obesity in patients with type 2 diabetes, where only $10 \%$ of patients with type 2 diabetes had normal body mass indexes (BMI), while the remaining patients were either overweight $(31 \%)$ or obese $(59 \%)$.

Worldwide, an estimated 41 million people died of noncommunicable diseases (NCDs) in 2016, corresponding to $71 \%$ of all deaths. Cardiovascular diseases (17.9 million deaths), cancer (9.0 million deaths), chronic respiratory diseases (3.8 million deaths), and diabetes (1.6 million deaths) were the four greatest contributors of NCDs related deaths. The increasing mortality rates in diabetic cases are related with the rising prevalence of obesity and other factors (World Health Organization, 2020).

Obesity has been linked to increased risk of various chronic diseases, including type 2 diabetes, coronary artery disease, stroke, and fatty liver (Censin et al., 2019). Moreover, diabetes is strongly related with nephropathy, retinopathy, neuropathy (Nathan et al., 2015; Garofolo et al., 2019), and erectile dysfunction (Kouidrat et al., 2017; Carrillo-Larco et al., 2018). These diseases are associated with increased risk of cardiovascular disease, elevated mortality, low quality of life (Silveira et al., 2020), and increased financial burden to health care systems. Therefore, diabetes and obesity are considered important global public health concerns (Hex et al., 2012).

\section{VASCULAR COMPLICATIONS OF DIABETES AND OBESITY}

Type 2 diabetes is associated with the onset of microvascular complications, such as nephropathy, retinopathy and neuropathy, as well as macrovascular complications, including coronary artery disease and cerebrovascular disease (Litwak et al., 2013; Kosiborod et al., 2018). A study by van Wijngaarden et al. (2017) demonstrated that the greater and more prolonged exposure to hyperglycemia, enhances the risk of both microvascular and macrovascular complications in patients with type 2 diabetes (van Wijngaarden et al., 2017). Comparably, intensive glucose control significantly reduced adverse outcomes due to major macrovascular or microvascular events (Patel et al., 2008). Moreover, obesity and type 2 diabetes mellitus in adolescents, predispose this group to higher vascular disease risk (Ryder et al., 2020). As well, overweight and obese individuals had an increased risk for major cardiovascular events, such as: myocardial infarction, stroke, and heart failure (Ärnlöv et al., 2010). Additionally, there are several factors that contribute to the vascular dysfunction associated with diabetes. Chronic hyperglycemia has been shown to impair endotheliumdependent vasodilatation in diabetes (Mäkimattila et al., 1996). Elevated advanced glycation end products (AGEs) has been shown to cause endothelial dysfunction (Xu B. et al., 2003; Ren et al., 2017). Similarly, increased oxidative stress can reduce nitric oxide (NO) bioavailability (Nassar et al., 2002; Cho et al., 2013), while augmented peroxynitrite may inactivate endothelial nitric oxide synthase (eNOS) (Chen et al., 2010; Cassuto et al., 2014). 
As well, augmented vascular contractility (Xie et al., 2006; Matsumoto et al., 2014; Lubomirov et al., 2019), increased vascular inflammation (Zhang et al., 2008; Ku and Bae, 2016), and stimulated endothelial cells apoptosis (Sheu et al., 2005, Sheu et al., 2008) can cooperate to cause vascular dysfunction (Figure 1A). There are key processes in obesity which collaborate and lead to impairment of vascular function. These processes include enhanced vascular contractility (Boustany-Kari et al., 2007; Weil et al., 2011), augmented sympathetic control of vasoconstriction (Haddock and Hill, 2011), elevated oxidative stress (La Favor et al., 2016), increased peroxynitrite (Mason et al., 2011; Gamez-Mendez et al., 2015), perivascular adipose tissue (PVAT) dysfunction (Ma et al., 2010; Bussey et al., 2016), increased arginase activity (which can reduce L-arginine and NO bioavailability) (Johnson et al., 2015; Bhatta et al., 2017), and increased vascular inflammation (Yao et al., 2017; Figure 1B). Both diabetes and obesity share common mechanisms that result in vascular injury. Thus, elucidation of the mechanisms underlying vascular dysfunction in these cardiometabolic diseases is essential to provide additional therapeutic targets in the prevention and treatment of these cardiometabolic diseases. Interestingly, alterations in TRPs channel expression or/and function may contribute to these pathological conditions, making these channels promising therapeutic targets.

\section{TRP CHANNELS}

The TRP superfamily was originally discovered in the study on Drosophila melanogaster, where in response to bright light, Drosophila mutants behaved as if they were blind, while wildtype flies maintained oriented toward visual cues. Thus, in the mutated eye, the light-response was transient during sustained light (Cosens and Manning, 1969). This mutant was known as TRP due to the transient response to prolonged intense lights, performed by Minke and colleagues (Minke et al., 1975). Following these reports, the molecular characterization of the Drosophila TRP gene was described (Montell and Rubin, 1989).

In addition, a common feature in the TRP superfamily is its tetrameric structure, where each subunit is constituted by six transmembrane segments, a pore-forming region between the segments S5-S6 and cytoplasmic amino and carboxyl termini (For general explanation, see reviews by: Earley and Brayden, 2015; Hof et al., 2019). Mammalian genomes encode 28 distinct TRP protein subunits, and this superfamily is divided into six subfamilies, based on amino acid sequence homology and include: TRPC (Wes et al., 1995; Liu et al., 2008), TRPV (Caterina et al., 1997; Smith et al., 2002), TRPM (Tsavaler et al., 2001; Fujiwara and Minor, 2008), TRPA (Story et al., 2003; Cvetkov et al., 2011), TRPP (Mochizuki et al., 1996; Giamarchi et al., 2010), and TRPML (Sun et al., 2000; Zeevi et al., 2010).

The TRP superfamily consists of a diverse group of cation channels, where most of the channels are non-selective and permeable to $\mathrm{Ca}^{2+}$ (Gonzalez-Perrett et al., 2001; Feng et al., 2014; Sierra-Valdez et al., 2018). These channels have been shown to be involved in many physiological processes, such as responses to painful stimuli (Caterina et al., 2000; Davis et al., 2000), repletion of intracellular calcium stores (Rosado et al., 2002), vasoconstriction/vasorelaxation (Freichel et al., 2001; Dietrich et al., 2005), secretion of hormones (Togashi et al., 2006; Cheng et al., 2007), cell cycle modulation (Lee et al., 2011; Tajeddine and Gailly, 2012), sensory perception (Kichko et al., 2018) and others. This superfamily displays a variety of activation mechanisms, such as ligand binding (Janssens et al., 2016), temperature (McKemy et al., 2002), endogenous chemical mediators (Beck et al., 2006), voltage (Matta and Ahern, 2007), G protein-coupled receptors (Boulay et al., 1997), and tyrosine kinase receptors (Xu H. et al., 2003; Vazquez et al., 2004), among other stimuli.

In blood vessels, TRP channels are present in endothelial cells (Ching et al., 2011), vascular smooth muscle cell (VSMC) (Johnson et al., 2009), PVAT (Sukumar et al., 2012), perivascular sensory nerves (Zygmunt et al., 1999), and pericytes (Tóth et al., 2005), and these channels have been implicated in the regulation of vascular tone (Pórszász et al., 2002; Qian et al., 2007; Earley et al., 2009), vascular cell proliferation (Zhang et al., 2018), vascular wall permeability (Tiruppathi et al., 2002; Paria et al., 2004), and angiogenesis (Hamdollah Zadeh et al., 2008; Ge et al., 2009). Additionally, there are a large number of studies describing the involvement of TRP proteins in various pathophysiological conditions. We focus on altered expression and/or activity of the TRPC, TRPV, TRPM, and TRPML channels, contributing to vascular dysfunction in obese and diabetic conditions or are potentially associated to vascular alterations.

\section{TRP CHANNELS INVOLVED IN VASCULAR COMPLICATIONS OF DIABETES AND OBESITY}

\section{The Role of TRPC in the Vasculature Under Diabetic and Obese Conditions}

The TRPC subfamily consists of seven proteins, known as TRPC1 to TRPC7 (see review of Clapham et al., 2001; Putney, 2005; Dietrich et al., 2010; Mederos y Schnitzler et al., 2018). TRPC channels can form homo- and heterotetramers (Hofmann et al., 2002; Strübing et al., 2003). Moreover, there is increasing evidence that TRPC channel members can form receptoroperated channels (ROC) (Soboloff et al., 2005; PeppiattWildman et al., 2007; Tai et al., 2008; Inoue et al., 2009; Itsuki et al., 2014) and store-operated channels (SOC) (Groschner et al., 1998; Freichel et al., 2001; Xu and Beech, 2001; Xu et al., 2006; Shi et al., 2016).

TRPC1, TRPC3, TRPC4, TRPC5, and TRPC6 are expressed in VSMC (Wang et al., 2004; Evans et al., 2009; Inoue et al., 2009; Mita et al., 2010) and endothelial cells (Yip et al., 2004; Gao et al., 2012; Sundivakkam et al., 2012). TRPC channels are involved in the regulation of vascular tone through different signaling pathways. For example, activation of TRPC1 and TRPC3 channels in the VSMC can cause depolarization and vasoconstriction (Reading et al., 2005; Wölfle et al., 2010). Alternatively, TRPC1 channels can be associated with largeconductance $\mathrm{Ca}^{2+}$-activated $\mathrm{K}^{+}\left(\mathrm{BK}_{C a}\right)$ channels in VSMC, 
A

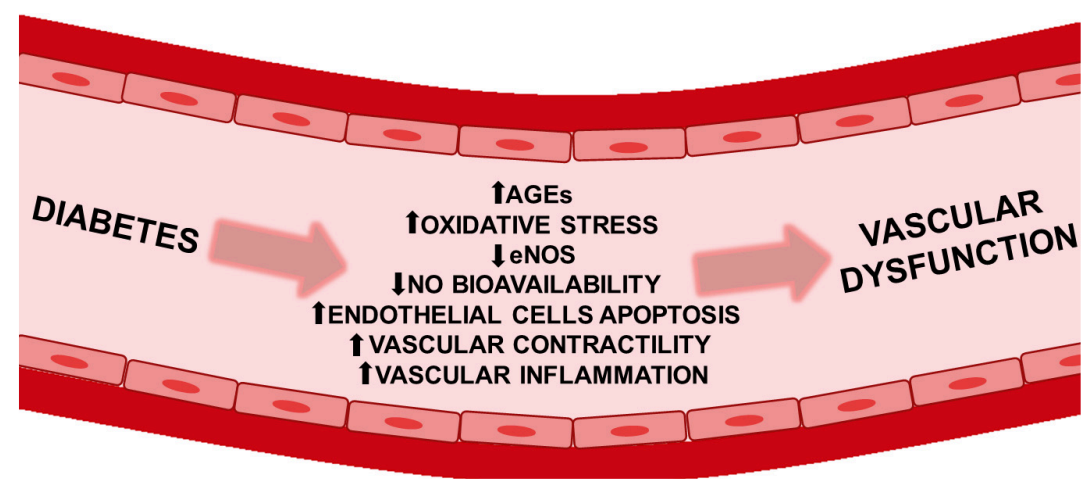

B
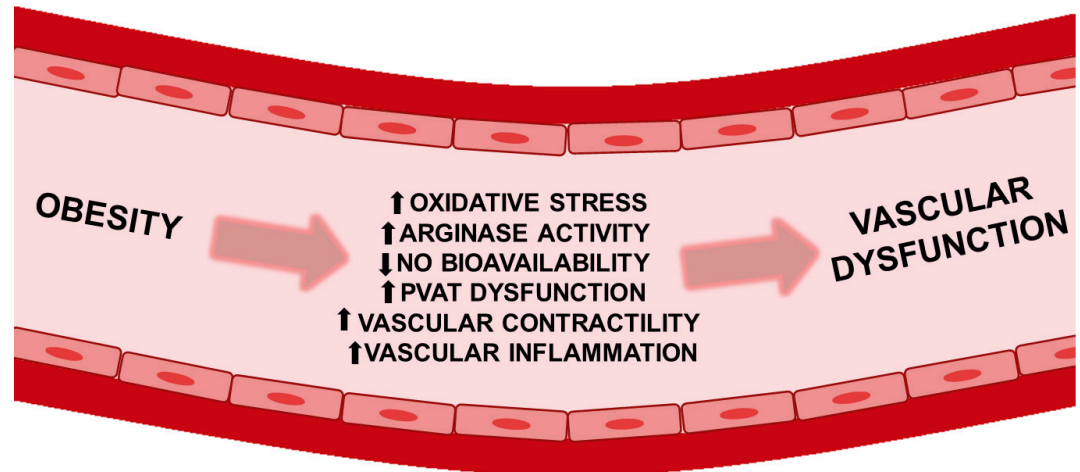

FIGURE 1 | Vascular dysfunction in diabetes and obesity. Pathophysiological factors leading to vascular dysfunction in (A) diabetic and (B) obese patients. AGEs, advanced glycation end products; eNOS, endothelial nitric oxide synthase; NO, nitric oxide; PVAT, perivascular adipose tissue.

indirectly activating cell hyperpolarization (Kwan et al., 2009). As well, TRPC1, TRPC3, and TRPC4 stimulation in endothelial cells can induce vasodilation through increases in endothelial $\mathrm{Ca}^{2+}$, with subsequent generation of $\mathrm{NO}$ (Freichel et al., 2001; Huang et al., 2011; Qu et al., 2017) and/or TRPC3 activation can induce endothelium-dependent hyperpolarization factor (EDHF)-mediated vasodilation (Kochukov et al., 2014). However, only a few studies have demonstrated the involvement of TRPC channels in the vasculature of diabetic animals and humans and no studies have investigated a role for TRPC in obesity.

Evans et al. (2009) showed that angiotensin-II (Ang-II)induced $\mathrm{Ca}^{2+}$ influx was significantly enhanced in cultured aortic VSMC from Goto-Kakizaki (GK) rats, a model of type 2 diabetes, when compared with cells from Wistar-Kyoto (WKY) control rats. TRPC1 and TRPC5 protein expression were similar, while TRPC4 protein expression was significantly increased, and TRPC6 protein expression was significantly decreased in GK, compared with WKY values. In GK-VSMC, Ang-II-induced $\mathrm{Ca}^{2+}$ influx was more sensitive to the calcium influx inhibitors 2-aminoethoxydiphenyl borate (2-APB) and caffeine, which act through the inhibition of the inositol 1,4,5-trisphosphate receptor $\left(\mathrm{IP}_{3} \mathrm{R}\right)$. Since TRPC1 can be activated by an $\mathrm{IP}_{3} \mathrm{R}$ coupling mechanism, this result suggests a possible increased activation of mechanisms contributing to TRPC1 activity. The authors of this study proposed that the elevated calcium influx induced by
Ang-II was due to the alteration of TRPC1/4/5 activity in diabetic rats (Evans et al., 2009). However, 2-APB and caffeine are nonselective inhibitors and therefore, the general absence of selective pharmacological tools for TRPC channels is a study limitation. Additionally, 2-APB and caffeine cannot be considered as specific reagents to evaluate TRPC1 activity. Therefore, the use of gene knockout or knockdown animals could offer a valuable alternative for studying specific functions of TRPC channels in the regulation of vascular tone in diabetic conditions. However, a limitation of this approach is that when one TRPC channel is downregulated or knocked out it may be compensated by other TRPCs, as evidenced by Dietrich et al. (2005). Therefore, these obstacles make difficult to draw correct conclusions about the role of TRPC channels on the obesity and diabetes.

A study by Chung and colleagues provided the first evidence that TRPC1, TRPC4 and TRPC6 messenger RNA (mRNA) and proteins are present in human saphenous vein, and their expression levels are modulated by type II diabetes. The authors demonstrated that cyclopiazonic acid (CPA)-induced contraction of the saphenous vein was greater in diabetic vessels than the non-diabetic, suggesting that the increased contractility in human diabetes could be partially due to the participation of $\mathrm{Ca}^{2+}$ entry through SOC. Additionally, TRPC channels may be involved in SOC. Although TRPC4 mRNA expression was elevated, protein levels were not significantly different when compared to non-diabetic vessels. TRPC1 and TRPC6 mRNA 
levels in diabetic conditions were similar to the control, however, protein expression was decreased in diabetic veins. Even though TPRC protein expression was diminished in the diabetic samples, the enhanced CPA-induced contraction in diabetic veins might be associated with increased TRPC activity, leading to higher capacitative $\mathrm{Ca}^{2+}$ entry (Chung et al., 2009).

Mita and colleagues demonstrated that TRPC1, TRPC3, and TRPC6 mRNAs and proteins were expressed in caudal arteries from Wistar rats. However, in addition to the expression of these TRPC channels, TRPC4 also was expressed at extremely low levels in GK rats. In addition, GK rats had a significant increase in protein expression of TRPC1 and TRPC6 channels or appearance of TRPC4 channel expression, but not TRPC3, compared with Wistar rats, which is associated with the reduction in cirazolineor CPA-induced contractions in GK (Mita et al., 2010).

These authors demonstrated that TRPC channel expression levels and function are altered in diabetes (Table 1). However, there was a heterogeneity of findings among these studies, therefore these discrepancies may be explained by a number of factors, including: variations in the metabolic profile of the diabetic animals, distinct stages of diabetes, and the type of arteries and veins investigated. Nevertheless, the in vivo significance of these findings has not been shown. Additionally, the role of TRPCs in obesity should also be more completely explored in future studies.

\section{The Role of TRPM2 in the Vasculature Under Diabetic and Obese Conditions}

TRPM2 is activated by $\mathrm{H}_{2} \mathrm{O}_{2}$ (Hara et al., 2002), adenosine $5^{\prime}$ diphosphoribose (ADP-ribose) (Heiner et al., 2003; Yu et al., 2017), nicotinic acid-adenine dinucleotide phosphate (NAADP) (Beck et al., 2006), $\mathrm{Ca}^{2+}$ (McHugh et al., 2003), and temperature $\left(35-47^{\circ} \mathrm{C}\right)$ (Togashi et al., 2006; Kashio et al., 2012; Kashio and Tominaga, 2017), while adenosine monophosphate (AMP) (Beck et al., 2006; Lange et al., 2008) and acidic pH are negative regulators (Du et al., 2009; Starkus et al., 2010). This channel is expressed in VSMC (Yang et al., 2006) and vascular endothelial cells (Hecquet et al., 2008), and it is permeable to $\mathrm{Ca}^{2+}, \mathrm{Na}^{+}$ (Perraud et al., 2001; Sano et al., 2001; Kraft et al., 2004), and $\mathrm{K}^{+}$(Sano et al., 2001). Moreover, physiological splice variants of TRPM2, including full-length TRPM2 (TRPM2-L) and a short splice variant (TRPM2-S), have been identified in endothelial cells (Hecquet and Malik, 2009; Hecquet et al., 2014) and VSMC (Yang et al., 2006).

TRPM2 is involved in endothelial permeability, as demonstrated by $\mathrm{H}_{2} \mathrm{O}_{2}$-induced $\mathrm{Ca}^{2+}$ influx via TRPM2 channels that results in endothelial hyperpermeability (Hecquet et al., 2008). Moreover, $\mathrm{H}_{2} \mathrm{O}_{2}$ activates TRPM2 to induce excessive $\mathrm{Ca}^{2+}$ influx, resulting in $\mathrm{Ca}^{2+}$ overload and consequently, cell death in vascular endothelial cells (Sun et al., 2012). Furthermore, ROS overproduction activates TRPM2 channels, leading to $\mathrm{Ca}^{2+}$ influx through TRPM2, which induces VSMC migration and proliferation that contributes to neointimal hyperplasia (Ru et al., 2015).

There are only a few studies that demonstrate changes in TRPM2 channel expression and/or function associated with diabetes and obesity. In pulmonary arteries from streptozotocin (STZ)-treated hyperglycemic lean Zucker (LZ) rats (type I diabetic), the TRPM2-L channel isoform was decreased when compared to controls. Contrarily, vascular superoxide levels, NADPH oxidase (NOX) activity and lung capillary filtration coefficient (Kf) are higher in STZ-treated LZ rats. Interestingly, inhibition of TRPM2 channel diminished lung Kf in diabetic rats but did not affect the $\mathrm{Kf}$ in control animals. The authors of this study proposed that in hyperglycemic rats, increased oxidative stress activates the TRPM2 channel and elevates pulmonary endothelial Kf. The decreased TRPM2L expression through chronic hyperglycemia may be due to overexposure of superoxide and a subsequent negative feedback-mediated downregulation. This enhanced the TRPM2 activation-mediated increase in $\mathrm{Kf}$ that can contribute to the elevated susceptibility to lung complications observed in individuals with type I diabetes. Taken together, additional studies are needed to determine the pulmonary TRPM2 channel sensitivity in control and diabetic animal models by using electrophysiological and pharmacological tools (Lu et al., 2014; Figures 2A,B).

A study developed by Sun et al. (2019) demonstrated that TRPM2 expression significantly increased in both primary mouse aortic endothelial cells and aortic endothelium from high-fat diet (HFD, $60 \mathrm{kcal} \%$ fat)-fed mice. In addition, preincubation of the TRPM2 inhibitor $N$-(p-amylcinnamoyl) anthranilic acid $(20 \mu \mathrm{M})$, reduced the impaired insulin-induced relaxation in aortas from HFD-fed mice. Similarly, knockdown of TRPM2 alleviated endothelial insulin resistance and improved endothelium-dependent vasodilatation in obese mice. The authors proposed that free fatty acid-induced $\mathrm{H}_{2} \mathrm{O}_{2}$ activation of TRPM2, thereby aggravating endothelial insulin resistance. Therefore, downregulation or pharmacological inhibition of TRPM2 channels may contribute to treatment of endothelial dysfunction associated with the oxidative stress state (Sun et al., 2019; Figures 2A,C). Both of these studies indicated that increased oxidative stress, present in diabetes and obesity, are modulating the TRPM2 channel (Table 1), leading to elevated channel activity. In this context, the decreased vascular TRPM2$\mathrm{L}$ expression in the lung from diabetic animals, as shown by $\mathrm{Lu}$ et al., is due to negative feedback.

\section{The Role of TRPV1 in the Vasculature Under Diabetic and Obese Conditions}

TRPV1 channels are expressed in endothelial cells (Yang et al., 2010), VSMC (Kark et al., 2008), perivascular sensory nerves (Zygmunt et al., 1999; Breyne and Vanheel, 2006), and pericytes (Tóth et al., 2005). TRPV1 channels are present in blood vessels, such as epineural arterioles (Davidson et al., 2006), aorta (Ohanyan et al., 2011; Sun et al., 2013), mesenteric (Sun et al., 2013; Zhang et al., 2015), and coronary arteries (Bratz et al., 2008). These channels are activated by multiple stimuli, including heat $\left(\sim 42-51^{\circ} \mathrm{C}\right)$ (Tominaga et al., 1998; Cesare et al., 1999), anandamide (Zygmunt et al., 1999), and exogenous agonists, such as capsaicin and resiniferatoxin (Caterina et al., 1997), as well as low $\mathrm{pH}$ that acts as a sensitizing agent 
TABLE 1 | TRP channels involved in vascular complications of diabetes and obesity.

\begin{tabular}{|c|c|c|c|c|c|c|c|}
\hline \multicolumn{8}{|c|}{ TRP channels involved in vascular complications of diabetes and obesity } \\
\hline Channel & $\begin{array}{l}\text { Diabetic } \\
\text { and/or } \\
\text { obesity model }\end{array}$ & $\begin{array}{l}\text { Normal } \\
\text { control }\end{array}$ & Tissue & $\begin{array}{l}\text { Drug-induced vascular } \\
\text { effect or other vascular } \\
\text { investigations }\end{array}$ & $\begin{array}{l}\text { mRNA in diabetic } \\
\text { and/or obesity } \\
\text { model }\end{array}$ & $\begin{array}{l}\text { Protein in } \\
\text { diabetic and/or } \\
\text { obesity model }\end{array}$ & References \\
\hline TRPC1 & $\begin{array}{l}\text { Goto-Kakizaki } \\
\text { (GK) (Type } 2 \\
\text { diabetes) }\end{array}$ & $\begin{array}{l}\text { Wistar- } \\
\text { Kyoto } \\
\text { (WKY) rat }\end{array}$ & $\begin{array}{l}\text { Cultured aortic } \\
\text { vascular smooth } \\
\text { muscle cell }\end{array}$ & $\begin{array}{l}\text { Angiotensin-II-induced } \mathrm{Ca}^{2+} \\
\text { influx was enhanced in } \\
\text { diabetic rat }\end{array}$ & Decrease & No change & $\begin{array}{l}\text { Evans et al. } \\
(2009)\end{array}$ \\
\hline TRPC1 & $\begin{array}{l}\text { Human Type II } \\
\text { diabetic }\end{array}$ & $\begin{array}{l}\text { Human } \\
\text { non- } \\
\text { diabetic }\end{array}$ & Saphenous vein & $\begin{array}{l}\text { Cyclopiazonic acid-induced } \\
\mathrm{Ca}^{2+} \text { influx was enhanced in } \\
\text { diabetic patient }\end{array}$ & No change & Decrease & $\begin{array}{l}\text { Chung et al. } \\
\text { (2009) }\end{array}$ \\
\hline TRPC1 & GK rat & Wistar rats & $\begin{array}{l}\text { Endothelium- } \\
\text { denuded } \\
\text { caudal artery } \\
\text { smooth muscle } \\
\text { strips }\end{array}$ & $\begin{array}{l}\text { Cirazoline- or cyclopiazonic } \\
\text { acid-induced } \mathrm{Ca}^{2+} \text { influx was } \\
\text { decreased in diabetic rat }\end{array}$ & - & Increase & $\begin{array}{l}\text { Mita et al. } \\
(2010)\end{array}$ \\
\hline TRPC3 & GK rat & WKY rat & $\begin{array}{l}\text { Cultured aortic } \\
\text { vascular smooth } \\
\text { muscle cell }\end{array}$ & $\begin{array}{l}\text { Angiotensin-II-induced } \mathrm{Ca}^{2+} \\
\text { influx was enhanced in } \\
\text { diabetic rat }\end{array}$ & Undetectable & - & $\begin{array}{l}\text { Evans et al. } \\
\text { (2009) }\end{array}$ \\
\hline TRPC3 & GK rat & Wistar rat & $\begin{array}{l}\text { Endothelium- } \\
\text { denuded } \\
\text { caudal artery } \\
\text { smooth muscle } \\
\text { strips }\end{array}$ & $\begin{array}{l}\text { Cirazoline- or cyclopiazonic } \\
\text { acid-induced } \mathrm{Ca}^{2+} \text { influx was } \\
\text { decreased in diabetic rat }\end{array}$ & - & No change & $\begin{array}{l}\text { Mita et al. } \\
(2010)\end{array}$ \\
\hline TRPC4 & GK rat & WKY rat & $\begin{array}{l}\text { Cultured aortic } \\
\text { vascular smooth } \\
\text { muscle cell }\end{array}$ & $\begin{array}{l}\text { Angiotensin-II-induced } \mathrm{Ca}^{2+} \\
\text { influx was enhanced in } \\
\text { diabetic rat }\end{array}$ & No change & Increase & $\begin{array}{l}\text { Evans et al. } \\
(2009)\end{array}$ \\
\hline TRPC4 & Human diabetic & $\begin{array}{l}\text { Human } \\
\text { non- } \\
\text { diabetic }\end{array}$ & Saphenous vein & $\begin{array}{l}\text { Cyclopiazonic acid-induced } \\
\mathrm{Ca}^{2+} \text { influx was enhanced in } \\
\text { diabetic patient }\end{array}$ & Increase & No change & $\begin{array}{l}\text { Chung et al. } \\
\text { (2009) }\end{array}$ \\
\hline TRPC4 & GK rat & Wistar rat & $\begin{array}{l}\text { Endothelium- } \\
\text { denuded } \\
\text { caudal artery } \\
\text { smooth muscle } \\
\text { strips }\end{array}$ & $\begin{array}{l}\text { Cirazoline- or cyclopiazonic } \\
\text { acid-induced } \mathrm{Ca}^{2+} \text { influx was } \\
\text { decreased in diabetic rat }\end{array}$ & $\begin{array}{l}\text { TRPC4 mRNA was } \\
\text { not detected in } \\
\text { Wistar rats, but it } \\
\text { was detectable in } \\
\text { GK rats }\end{array}$ & $\begin{array}{l}\text { TRPC4 protein was } \\
\text { not detected in } \\
\text { Wistar rats, but it } \\
\text { was barely } \\
\text { detectable in GK } \\
\text { rats }\end{array}$ & $\begin{array}{l}\text { Mita et al. } \\
(2010)\end{array}$ \\
\hline TRPC5 & GK rat & WKY rat & $\begin{array}{l}\text { Cultured aortic } \\
\text { vascular smooth } \\
\text { muscle cell }\end{array}$ & $\begin{array}{l}\text { Angiotensin-II-induced } \mathrm{Ca}^{2+} \\
\text { influx was enhanced in } \\
\text { diabetic rat }\end{array}$ & No change & No change & $\begin{array}{l}\text { Evans et al. } \\
(2009)\end{array}$ \\
\hline TRPC6 & GK rat & WKY rat & $\begin{array}{l}\text { Cultured aortic } \\
\text { vascular smooth } \\
\text { muscle cell }\end{array}$ & $\begin{array}{l}\text { Angiotensin-II-induced } \mathrm{Ca}^{2+} \\
\text { influx was enhanced in } \\
\text { diabetic rat }\end{array}$ & Decrease & Decrease & $\begin{array}{l}\text { Evans et al. } \\
\text { (2009) }\end{array}$ \\
\hline TRPC6 & Human diabetic & $\begin{array}{l}\text { Human } \\
\text { non- } \\
\text { diabetic }\end{array}$ & Saphenous vein & $\begin{array}{l}\text { Cyclopiazonic acid-induced } \\
\mathrm{Ca}^{2+} \text { influx was enhanced in } \\
\text { diabetic patient }\end{array}$ & No change & Decrease & $\begin{array}{l}\text { Chung et al. } \\
\text { (2009) }\end{array}$ \\
\hline TRPC6 & GK rat & Wistar rat & $\begin{array}{l}\text { Endothelium- } \\
\text { denuded } \\
\text { caudal artery } \\
\text { smooth muscle } \\
\text { strips }\end{array}$ & $\begin{array}{l}\text { Cirazoline- or cyclopiazonic } \\
\text { acid-induced } \mathrm{Ca}^{2+} \text { influx was } \\
\text { decreased in diabetic rat }\end{array}$ & - & Increase & $\begin{array}{l}\text { Mita et al. } \\
(2010)\end{array}$ \\
\hline TRPM2 & $\begin{array}{l}\text { Streptozotocin } \\
\text { (STZ)-treated } \\
\text { lean Zucker } \\
\text { (LZ) rats (Type I } \\
\text { diabetes) }\end{array}$ & $\begin{array}{l}\text { Lean } \\
\text { Zucker rats }\end{array}$ & Pulmonary artery & $\begin{array}{l}\text { Lung capillary filtration } \\
\text { coefficient (Kf) was enhanced } \\
\text { in diabetic rat. TRPM2 channel } \\
\text { mediated increase in Kf. }\end{array}$ & - & Decrease & $\begin{array}{l}\text { Lu et al. } \\
\text { (2014) }\end{array}$ \\
\hline TRPM2 & $\begin{array}{l}\text { High-fat diet } \\
\text { (HFD)-fed mice } \\
\text { C57BL/6J for } \\
16 \text { weeks. }\end{array}$ & $\begin{array}{l}\text { Low-fat diet } \\
\text { (LFD)-fed } \\
\text { mice } \\
\text { C57BL/6J } \\
\text { for } \\
16 \text { weeks. }\end{array}$ & $\begin{array}{l}\text { Mouse aortic } \\
\text { endothelial cells } \\
\text { and aortas }\end{array}$ & $\begin{array}{l}\text { Preincubation of TRPM2 } \\
\text { inhibitor } \mathrm{N} \text {-(p-amylcinnamoyl) } \\
\text { anthranilic acid ( } 20 \mu \mathrm{M}) \text { or } \\
\text { knockdown of TRPM2 } \\
\text { alleviates obesity-associated } \\
\text { impairment in insulin-evoked } \\
\text { endothelium-dependent } \\
\text { relaxations in obese mice }\end{array}$ & - & Increase & $\begin{array}{l}\text { Sun et al. } \\
(2019)\end{array}$ \\
\hline
\end{tabular}


TABLE 1 | Continued

\begin{tabular}{|c|c|c|c|c|c|c|c|}
\hline \multicolumn{8}{|c|}{ TRP channels involved in vascular complications of diabetes and obesity } \\
\hline Channel & $\begin{array}{l}\text { Diabetic } \\
\text { and/or } \\
\text { obesity model }\end{array}$ & $\begin{array}{l}\text { Normal } \\
\text { control }\end{array}$ & Tissue & $\begin{array}{l}\text { Drug-induced vascular } \\
\text { effect or other vascular } \\
\text { investigations }\end{array}$ & $\begin{array}{l}\text { mRNA in diabetic } \\
\text { and/or obesity } \\
\text { model }\end{array}$ & $\begin{array}{l}\text { Protein in } \\
\text { diabetic and/or } \\
\text { obesity model }\end{array}$ & References \\
\hline TRPV1 & $\begin{array}{l}\text { Zucker } \\
\text { diabetic fatty } \\
\text { (ZDF) rat (Type } \\
\text { II diabetes) }\end{array}$ & $\begin{array}{l}\text { Genetic } \\
\text { controls }\end{array}$ & $\begin{array}{l}\text { Branch II and III } \\
\text { mesenteric } \\
\text { arteries. } \\
\text { (A portion of } \\
\text { the omental } \\
\text { membrane, } \\
\text { which frequently } \\
\text { contains nerve } \\
\text { trunks, was } \\
\text { maintained) }\end{array}$ & $\begin{array}{l}\text { Capsaicin-induced relaxation } \\
\text { was similar in diabetic rat. }\end{array}$ & - & - & $\begin{array}{l}\text { Pamarthi } \\
\text { et al. (2002) }\end{array}$ \\
\hline TRPV1 & $\begin{array}{l}\text { STZ -induced } \\
\text { diabetic } \\
\text { Sprague- } \\
\text { Dawley } \\
\text { rats }\end{array}$ & $\begin{array}{l}\text { Sprague- } \\
\text { Dawley } \\
\text { rats }\end{array}$ & $\begin{array}{l}\text { Epineurial } \\
\text { arterioles of the } \\
\text { sciatic nerve }\end{array}$ & $\begin{array}{l}\text { Capsaicin-induced constriction } \\
\left(10^{-6} \mathrm{M}\right) \text { was decreased in } \\
\text { diabetic rat (10-12-week } \\
\text { duration). }\end{array}$ & - & Decrease & $\begin{array}{l}\text { Davidson } \\
\text { et al. (2006) }\end{array}$ \\
\hline TRPV1 & $\begin{array}{l}\text { STZ -induced } \\
\text { diabetic Wistar } \\
\text { rats }\end{array}$ & $\begin{array}{l}\text { Wistar rats } \\
\text { treated with } \\
\text { the solvent } \\
\text { for STZ }\end{array}$ & $\begin{array}{l}\text { Medial meningeal } \\
\text { artery } \\
\text { (Meningeal blood } \\
\text { flow) }\end{array}$ & $\begin{array}{l}\text { Capsaicin-induced relaxation } \\
\left(10^{-7} \mathrm{M}\right) \text { was abolished in } \\
\text { diabetic rat. } \\
\text { Capsaicin-induced constriction } \\
\left(10^{-5} \mathrm{M}\right) \text { was similar in } \\
\text { diabetic rat. }\end{array}$ & - & - & $\begin{array}{l}\text { Dux et al. } \\
(2007)\end{array}$ \\
\hline TRPV1 & $\begin{array}{l}\mathrm{db} / \mathrm{db} \text { mice } \\
\text { (Type } 2 \\
\text { diabetes and } \\
\text { obesity) }\end{array}$ & $\begin{array}{l}\text { C57BLKS/J } \\
\text { mice }\end{array}$ & $\begin{array}{l}\text { Mean arterial } \\
\text { blood pressure } \\
\text { (MAP) } \\
\text { Aortic tissue }\end{array}$ & $\begin{array}{l}\text { Capsaicin-induced increases } \\
\text { in MAP was attenuated in } \\
\text { diabetic mouse. }\end{array}$ & - & Decrease & $\begin{array}{l}\text { Ohanyan } \\
\text { et al. (2011) }\end{array}$ \\
\hline TRPV1 & $\mathrm{db} / \mathrm{db}$ mice & $\begin{array}{l}\text { C57BLKS/J } \\
\text { mice }\end{array}$ & $\begin{array}{l}\text { Coronary } \\
\text { microvessel } \\
\text { Myocardial blood } \\
\text { flow (MBF) }\end{array}$ & $\begin{array}{l}\text { Capsaicin-induced increases } \\
\text { in MBF and } \\
\text { capsaicin-mediated relaxation } \\
\text { in coronary microvessels were } \\
\text { attenuated in diabetic mouse. }\end{array}$ & - & - & $\begin{array}{l}\text { Guarini et al. } \\
(2012)\end{array}$ \\
\hline TRPV1 & $\mathrm{db} / \mathrm{db}$ mice & $\begin{array}{l}\text { C57BLKS/J } \\
\text { mice }\end{array}$ & $\begin{array}{l}\text { Thoracic aortas } \\
\text { and } \\
\text { mesenteric } \\
\text { arteries }\end{array}$ & $\begin{array}{l}\text { Dietary capsaicin improves the } \\
\text { endothelium-dependent } \\
\text { relaxation in diabetic mouse } \\
\text { compared to db/db mice given } \\
\text { a normal diet. }\end{array}$ & - & Decrease & $\begin{array}{l}\text { Sun et al. } \\
(2013)\end{array}$ \\
\hline TRPV1 & $\begin{array}{l}\text { STZ -induced } \\
\text { diabetic } \\
\text { Sprague- } \\
\text { Dawley } \\
\text { rats }\end{array}$ & $\begin{array}{l}\text { Sprague- } \\
\text { Dawley } \\
\text { rats }\end{array}$ & $\begin{array}{l}\text { Third branch of } \\
\text { the superior } \\
\text { mesenteric artery }\end{array}$ & $\begin{array}{l}\text { Capsaicin-induced relaxation } \\
\text { was decreased in diabetic rat. }\end{array}$ & - & Decrease & $\begin{array}{l}\text { Zhang et al. } \\
\text { (2015) }\end{array}$ \\
\hline TRPV1 & $\mathrm{db} / \mathrm{db}$ mice & $\begin{array}{l}\text { C57BLKS/J } \\
\text { mice }\end{array}$ & $\begin{array}{l}\text { Coronary } \\
\text { arterioles } \\
\text { Coronary blood } \\
\text { flow (CBF) }\end{array}$ & $\begin{array}{l}\mathrm{H}_{2} \mathrm{O}_{2} \text { had little potentiating } \\
\text { effect on capsaicin-induced } \\
\text { CBF responses or } \\
\text { capsaicin-mediated coronary } \\
\text { vasodilation in } \mathrm{db} / \mathrm{db} \text { and } \\
\text { TRPV1 knockout mice. }\end{array}$ & - & - & $\begin{array}{l}\text { DelloStritto } \\
\text { et al. (2016) }\end{array}$ \\
\hline TRPV1 & $\begin{array}{l}\text { Human diabetic } \\
\text { (Type } 1 \\
\text { diabetes) }\end{array}$ & $\begin{array}{l}\text { Human } \\
\text { non- } \\
\text { diabetic }\end{array}$ & $\begin{array}{l}\text { Cutaneous } \\
\text { vascular } \\
\text { conductance } \\
\text { (CVC) in the } \\
\text { forearm }\end{array}$ & $\begin{array}{l}\text { CVC was decreased in } \\
\text { diabetic patients in } \\
\text { response to local heating early } \\
\text { peak. }\end{array}$ & - & - & $\begin{array}{l}\text { Marche et al. } \\
(2017)\end{array}$ \\
\hline TRPV1 & $\begin{array}{l}\text { High-fat/high- } \\
\text { cholesterol } \\
\text { diet- induced } \\
\text { obese male } \\
\text { Ossabaw } \\
\text { miniature swine } \\
\text { for } 24 \text { weeks. }\end{array}$ & $\begin{array}{l}\text { Lean male } \\
\text { Ossabaw } \\
\text { miniature } \\
\text { swine for } \\
24 \text { weeks. }\end{array}$ & Coronary arteries & $\begin{array}{l}\text { Capsaicin-induced relaxation } \\
\text { was impaired in obese pigs. }\end{array}$ & Increase & Decrease & $\begin{array}{l}\text { Bratz et al. } \\
(2008)\end{array}$ \\
\hline
\end{tabular}


TABLE 1 | Continued

\begin{tabular}{|c|c|c|c|c|c|c|c|}
\hline \multicolumn{8}{|c|}{ TRP channels involved in vascular complications of diabetes and obesity } \\
\hline Channel & $\begin{array}{l}\text { Diabetic } \\
\text { and/or obesity } \\
\text { model }\end{array}$ & $\begin{array}{l}\text { Normal } \\
\text { control }\end{array}$ & Tissue & $\begin{array}{l}\text { Drug-induced vascular } \\
\text { effect or other vascular } \\
\text { investigations }\end{array}$ & $\begin{array}{l}\text { mRNA in diabetic } \\
\text { and/or obesity } \\
\text { model }\end{array}$ & $\begin{array}{l}\text { Protein in } \\
\text { diabetic and/or } \\
\text { obesity model }\end{array}$ & References \\
\hline TRPV1 & $\begin{array}{l}\text { HFD-fed } \\
\text { Sprague-Dawley } \\
\text { rats } \\
\text { for } \\
20-24 \text { weeks. }\end{array}$ & $\begin{array}{l}\text { Normal } \\
\text { diet-fed } \\
\text { Sprague- } \\
\text { Dawley rats } \\
\text { for } \\
20-24 \text { weeks. }\end{array}$ & $\begin{array}{l}\text { Small mesenteric } \\
\text { arteries } \\
\text { (third-order) }\end{array}$ & $\begin{array}{l}\text { Capsaicin }(10 \mu \mathrm{M}) \\
\text { significantly increased the } \\
\text { amplitude of nerve-mediated } \\
\text { contraction induced by } \\
10 \mathrm{~Hz} \text { stimulation, with a } \\
\text { greater effect in control than } \\
\text { obese animals. }\end{array}$ & - & - & $\begin{array}{l}\text { Haddock and } \\
\text { Hill (2011) }\end{array}$ \\
\hline TRPV1 & $\begin{array}{l}\text { HFD-fed mice } \\
\text { C57BL6/ } \\
\text { 129SVJ for } \\
12 \text { weeks. }\end{array}$ & $\begin{array}{l}\text { Normal } \\
\text { diet-fed mice } \\
\text { C57BL6/ } \\
\text { 129SVJ for } \\
12 \text { weeks. }\end{array}$ & Aorta & $\begin{array}{l}\text { Vascular hypertrophy was } \\
\text { observed in HFD-fed } \\
\text { wild-type but not HFD-fed } \\
\text { TRPV1 knockout mice. }\end{array}$ & - & - & $\begin{array}{l}\text { Marshall et al. } \\
\text { (2013) }\end{array}$ \\
\hline TRPV1 & $\begin{array}{l}\text { Obese Zucker } \\
(\mathrm{OZ}) \text { rats }\end{array}$ & $\llcorner Z$ rats & $\begin{array}{l}\text { Resistance } \\
\text { mesenteric } \\
\text { arteries }\end{array}$ & $\begin{array}{l}\text { Capsaicin-induced } \\
\text { relaxation } \\
\text { was decreased in OZ rats }\end{array}$ & - & No change & $\begin{array}{l}\text { Lobato et al. } \\
(2013)\end{array}$ \\
\hline TRPV1 & $\begin{array}{l}\text { High-fat, } \\
\text { high-sucrose } \\
\text { (HFHS) } \\
\text { diet-induced } \\
\text { obese } \\
\text { Sprague-Dawley } \\
\text { rats } \\
\text { for } 20 \text { weeks. }\end{array}$ & $\begin{array}{l}\text { Regular } \\
\text { diet-fed } \\
\text { Sprague- } \\
\text { Dawley rats } \\
\text { for } 20 \text { weeks. }\end{array}$ & $\begin{array}{l}\text { Meningeal blood } \\
\text { flow }\end{array}$ & $\begin{array}{l}\text { Capsaicin-induced } \\
\text { increased meningeal blood } \\
\text { flow (100 nM) was greater in } \\
\text { obese rat. } \\
\text { Capsaicin-induced } \\
\text { decreased meningeal blood } \\
\text { flow (10 } \mu \mathrm{M}) \text { was greater in } \\
\text { obese rat. }\end{array}$ & - & - & $\begin{array}{l}\text { Marics et al. } \\
(2017)\end{array}$ \\
\hline TRPV4 & $\begin{array}{l}\text { STZ -induced } \\
\text { diabetic } \\
\text { Sprague-Dawley } \\
\text { rats }\end{array}$ & $\begin{array}{l}\text { Sprague- } \\
\text { Dawley } \\
\text { rats }\end{array}$ & $\begin{array}{l}\text { Third or fourth } \\
\text { branches of rat } \\
\text { mesenteric artery }\end{array}$ & $\begin{array}{l}\text { TRPV4-K } \mathrm{Ca}_{2} \text {.3-mediated } \\
\text { relaxation were impaired in } \\
\text { diabetic rats }\end{array}$ & - & Decrease & $\begin{array}{l}\text { Ma et al. } \\
(2013)\end{array}$ \\
\hline TRPV4 & $\begin{array}{l}\text { STZ -induced } \\
\text { diabetic } \\
\text { Sprague-Dawley } \\
\text { rats }\end{array}$ & $\begin{array}{l}\text { Sprague- } \\
\text { Dawley } \\
\text { rats }\end{array}$ & Retinal arteriole & - & Decrease & Decrease & $\begin{array}{l}\text { Monaghan } \\
\text { et al. (2015) }\end{array}$ \\
\hline TRPV4 & $\begin{array}{l}\mathrm{db} / \mathrm{db} \text { mice } \\
\text { and STZ } \\
\text {-induced } \\
\text { diabetic } \\
\text { C57BLKS/J } \\
\text { mice }\end{array}$ & $\begin{array}{l}\text { C57BLKS/J } \\
\text { mice }\end{array}$ & Aortas & - & Decrease & Decrease & $\begin{array}{l}\text { Gao et al. } \\
(2020)\end{array}$ \\
\hline TRPV4 & $\begin{array}{l}\text { HFD-fed mice } \\
\text { C57BL/6J. } \\
\text { The diets } \\
\text { initiated at age } \\
5 \text { weeks and } \\
\text { continued at } \\
\text { age } 6 \text { months. }\end{array}$ & $\begin{array}{l}\text { LFD-fed mice } \\
\text { C57BL/6J. } \\
\text { The diets } \\
\text { initiated at } \\
\text { age } 5 \text { weeks } \\
\text { and } \\
\text { continued at } \\
\text { age } \\
6 \text { months. }\end{array}$ & $\begin{array}{l}\text { Third-order } \\
\text { mesenteric } \\
\text { arteries }\end{array}$ & $\begin{array}{l}\text { Vasodilatory responses to } \\
\text { GSK1016970A (TRPV4 } \\
\text { agonist) in resistance } \\
\text { mesenteric arteries were } \\
\text { similar between the LFD- } \\
\text { and HFD-fed mice. }\end{array}$ & - & - & $\begin{array}{l}\text { Greenstein } \\
\text { et al. (2020) }\end{array}$ \\
\hline TRPV4 & $\begin{array}{l}\text { HFD-fed mice } \\
\text { C57BL/6J } \\
\text { for } 14 \text { weeks. } \\
\text { Obese } \\
\text { individuals. }\end{array}$ & $\begin{array}{l}\text { LFD-fed mice } \\
\text { C57BL/6J } \\
\text { for } 14 \text { weeks. } \\
\text { Non-obese } \\
\text { individuals. }\end{array}$ & $\begin{array}{l}\text { Resistance } \\
\text { mesenteric } \\
\text { arteries from } \\
\text { mice. } \\
\text { Splenius/ } \\
\text { temporalis } \\
\text { muscle arteries } \\
\text { from human. }\end{array}$ & $\begin{array}{l}\text { Vasodilatory response to } \\
\text { GSK1016970A was } \\
\text { impaired in HFD mice. } \\
\text { Vasodilatory response to } \\
\text { GSK1016970A was } \\
\text { markedly reduced in the } \\
\text { arteries from obese } \\
\text { individuals. }\end{array}$ & - & - & $\begin{array}{l}\text { Ottolini et al. } \\
(2020)\end{array}$ \\
\hline
\end{tabular}

(Tominaga et al., 1998; Cesare et al., 1999). TRPV1 is a nonselective cation channel, which is permeable to $\mathrm{K}^{+}, \mathrm{Na}^{+}, \mathrm{Ca}^{2+}$, and $\mathrm{Mg}^{2+}$ (Caterina et al., 1997).
Activation of TRPV1 by capsaicin promotes the release of neurotransmitters, such as calcitonin gene-related peptide (CGRP) (Zygmunt et al., 1999; Wang et al., 2006) from 
capsaicin-sensitive nerves, in addition to NO from endothelial cells (Yang et al., 2010; Ching et al., 2011), which can diffuse to adjacent VSMC and cause relaxation. In smooth muscle cells from skeletal muscle arterioles obtained from the rat and mice, TRPV1 stimulation causes an increase in intracellular $\mathrm{Ca}^{2+}$ concentration, resulting in vasoconstriction (Czikora et al., 2012). Therefore, the activation of TRPV1 may induce different effects on the vasculature (vasoconstriction, vasodilation, or no effect), which can be unique to each vascular bed. For example, arteries with sensory neuron innervation and without vascular TRPV1 expression are expected to dilate in response to TRPV1 activation. However, arteries with elevated smooth muscle TRPV1 expression and without apparent sensory neuronal innervation constrict in response to the same TRPV1 stimulation (Kark et al., 2008; Tóth et al., 2014). Moreover, TRPV1 activation by capsaicin induced concentration-dependent biphasic effects, where a low concentration capsaicin evoked dilation, while a higher concentration resulted in vasoconstriction of the dural vessels (Dux et al., 2003) and skeletal (musculus gracilis) muscle arterioles (Kark et al., 2008).

Abundant evidence supports the hypothesis that altered TRPV1 expression and/or function is associated with vascular dysfunction in diabetes and obesity. The TRPV1 is the most studied TRP channel in the vasculature, under these metabolic conditions. In humans, a study by Marche et al. (2017) evaluated cutaneous vascular conductance (CVC) in response to heat by using a skin-heating probe, heated to $44^{\circ} \mathrm{C}$ to assess heat-induced vasodilation. The local heat-induced early peak is mediated through TRPV1 channels, located on sensory nerves. Therefore, the significantly diminished peak response to local thermal hyperemia could suggest reduced activity of the TRPV1 channels at the skin level in type 1 diabetic patients compared to control subjects. This study indicated that the microvascular response triggered by TRPV1 channels is reduced in type 1 diabetic patients (Marche et al., 2017).

Zhang et al. (2015) investigated the pharmacological effects of capsaicin on mesenteric arteries of STZ-induced diabetic Sprague-Dawley rats. Capsaicin-induced vasodilation was impaired in the mesenteric arteries of diabetic rats. As well, TRPV1 expression was reduced in the diabetic preparation when compared to the control group. The authors indicated that the attenuated expression of CGRP and TRPV1 contribute to the weakened capsaicin-mediated dilation in diabetic mesenteric arteries (Zhang et al., 2015). In line with previous studies, capsaicin-induced relaxation in resistance mesenteric arteries was markedly decreased in obese Zucker (OZ; genetic model of obesity) rats compared with LZ rats. However, TRPV1 receptor protein expression was similar between $\mathrm{LZ}$ and $\mathrm{OZ}$ rats. The authors suggest that the weakened vascular effect to anandamide in arteries from this obese model can involve reduced activation of $\mathrm{C}$-fiber nerve endings, and this may collaborate to the vascular dysfunction observed in $\mathrm{OZ}$ rats (Lobato et al., 2013). However, one concern about this model is due the mutation of the $f a$ gene (cause of obesity in OZ rats) is not common among humans.

In addition, the study by Dux et al. (2007) evaluated the TRPV1 receptor-mediated neurogenic sensory vasodilation in diabetic rats. In control and insulin-treated diabetic animals, capsaicin $\left(10^{-7} \mathrm{M}\right)$ induced increases in meningeal blood flow, but in 6-week STZ-induced diabetic rats, capsaicin promoted decreases in the blood flow. In contrast, capsaicin at a higher concentration $\left(10^{-5} \mathrm{M}\right)$ caused vasoconstriction, which is a non-neurogenic response and was similar in control and diabetic animals. The authors demonstrated a reduction in the capsaicin-evoked release of CGRP and decrease in the density of perivascular and stromal TRPV1-immunoreactive nerve fibers of the dura mater from diabetic rats, suggesting that insufficient vasodilator function of meningeal sensory nerves may contribute to the higher incidence of headaches in diabetics due to perturbation of tissue homeostasis that could induce additional activation and/or sensitization of meningeal nociceptors (Dux et al., 2007). Further studies are needed to determine if this hypothesis can be supported. It is pertinent to highlight the fact that diabetic rats treated with insulin restored the vasodilatory response and the capsaicin-evoked release of CGRP, indicating that impairments observed in diabetic animals can be attributed to the diabetic condition induced by STZ and not to a toxic action of this drug. Moreover, it is important to note, that the current evidences demonstrate that TRPV1 channels expression and/or activity in perivascular sensory nerves are reduced under these conditions.

In an opposite way, in model of obesity, topical administration of capsaicin $(100 \mathrm{nM})$ to the dura mater promoted enhanced meningeal blood flow in high-fat high-sucrose (HFHS) dietfed Sprague-Dawley rats (diets started at 6 weeks of age and continued for 20 weeks; $45 \%$ of total calories as fat) compared to regular diet-fed rats. However, administration of capsaicin at $10 \mu \mathrm{M}$ induced a greater reduction in meningeal blood flow in obese animals compared to controls. In this way, dural application of capsaicin resulted in significantly higher vasodilator and vasoconstrictor responses in obese animals compared to controls. Moreover, this obesity animal model was characterized by an increase in CGRP release in response to both concentrations of capsaicin administered, suggesting a greater TRPV1-mediated CGRP release from meningeal afferent nerves likely due to a sensitization of the TRPV1 receptor. This sensitization may be a consequence of the increase in proinflammatory cytokines and levels of oxidative stress. Changes in TRPV1-mediated vascular reactions and CGRP release, may be related to the enhanced headache susceptibility of obese individuals (Marics et al., 2017). Moreover, Dux et al. (2007) and Marics et al. (2017) demonstrated divergent results on TRPV1 receptor-mediated neurogenic sensory vasodilation between diabetic and obese conditions, indicating that different mechanisms can contribute to modulation of the TRPV1 channels in each disease.

Guarini et al. (2012) showed that capsaicin-mediated increases in myocardial blood flow (MBF), using myocardial contrast echocardiography, were reduced in $\mathrm{db} / \mathrm{db}$ mice, a model of type II diabetes, and obesity. Similarly, relaxation promoted by capsaicin was attenuated in coronary microvessels from diabetic mice. Interestingly, myocardial $\mathrm{pH}$ was more acidic in diabetic mice than control mice and $\mathrm{pH}$-mediated relaxation was attenuated in coronary microvessels from TRPV $1^{(-/-)}$and $\mathrm{db} / \mathrm{db}$ mice. The 

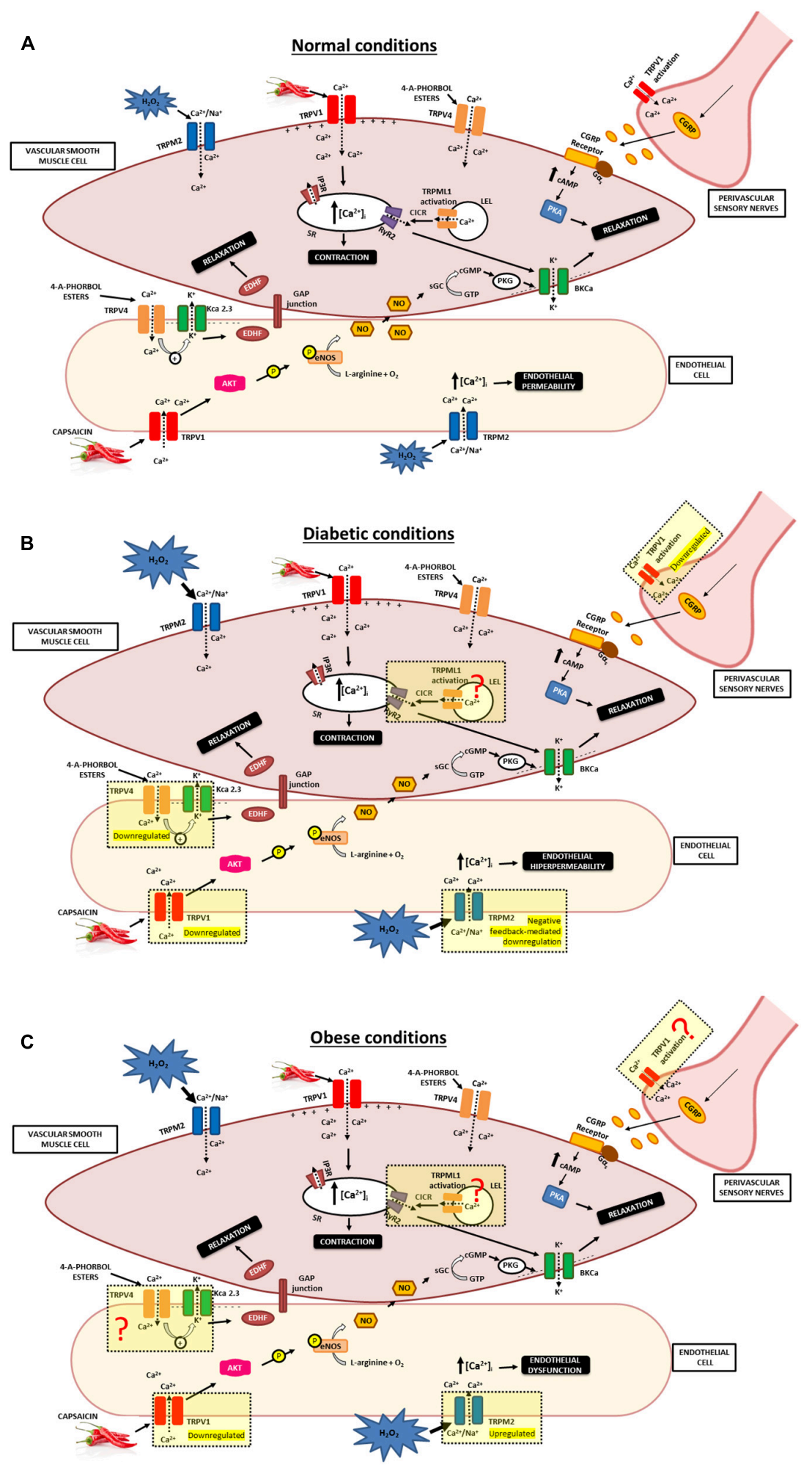

FIGURE 2 | Involvement of TRPs in vascular responses in normal, diabetic and obese conditions. (A) The figure shows the possible mechanisms that can explain vasodilator influences of TRPV1, TRPV4, TRPM2, and TRPML1 channel present in the vasculature. TRPV1 channel activation causes release of the CGRP from sensory nerves. CGRP binds to CGRP receptor, inducing augmented levels of CAMP that activates PKA and promotes relaxation of VSMC. TRPV1 activation in endothelial cells promotes $\mathrm{Ca}^{2+}$ influx and phosphorylation of eNOS and induces NO production. NO active the soluble guanylyl cyclase, that catalyzes the conversion of GTP to cGMP and active the PKG. The NO/CGMP/PKG activates BK $\mathrm{Ca}_{\mathrm{a}}$ that leads to smooth muscle relaxation. Additionally, specific interaction of 


\section{FIGURE 2 | Continued}

TRPV4 with $\mathrm{K}_{\mathrm{Ca}} 2.3$ in endothelial cells promote vasodilation, likely via an EDHF pathway. Moreover, $\mathrm{H}_{2} \mathrm{O}_{2}$-induced $\mathrm{Ca}^{2+}$ influx via TRPM2 channels in endothelial cells results in endothelial permeability. TRPML1 is closely associated with RyR2. TRPML1 activation provokes $\mathrm{Ca}^{2+}$ signals from a LELs, which can subsequently be augmented by CICR from the SR via RyR2 to induce $\mathrm{Ca}^{2+}$ sparks, leading to $\mathrm{BK}_{\mathrm{Ca}}$ channel activity that result in membrane hyperpolarization, VSMC relaxation. (B) The figure shows the possible alterations in TRPV1, TRPV4, and TRPM2 channel under diabetic conditions. Diabetic conditions promote reduction in the capsaicin-evoked release of CGRP and decrease in the density of perivascular TRPV1. Moreover, a high level of glucose reduces TRPV1 expression and PKA phosphorylation in endothelial cells. Additionality, hyperglycemia is a crucial factor for the diminished TRPV4 expression and impairs the endothelium-dependent vasodilatation. Also, increased oxidative stress activates the TRPM2 channel and results in endothelial hyperpermeability. Besides that, overexposure of superoxide promoted a TRPM2 channel negative feedback-mediated downregulation. Further studies are needed to clarify whether TRPML1 activity and/or expression are altered in the vasculature during diabetes. (C) The figure shows the possible alterations in TRPV1 and TRPM2 channel under obese conditions. Impaired capsaicin-induced vasodilation in arteries is associated with reduced expression of TRPV1 protein and cation influx into endothelial cells under obese conditions. Increased oxidative stress present in obesity are modulating the TRPM2 channel, leading elevated activity of this channel. Further studies are needed to elucidate whether TRPV4 and TRPML1 activity and/or expression are altered in the vasculature during obesity. TRPV1, Transient receptor potential of vanilloid type 1; TRPV4, Transient receptor potential of vanilloid type 4; TRPM2, Transient receptor potential of melastatin type 2; TRPML1, Transient receptor potential of mucolipin type 1; VSMC, vascular smooth muscle cells; NO, nitric oxide; EDHF, endothelium-derived hyperpolarizing factor; eNOS, endothelial nitric oxide synthase; $\mathrm{BK}_{\mathrm{Ca}}$, large-conductance $\mathrm{Ca}^{2+}$-activated $\mathrm{K}^{+}$channel; $\mathrm{K}_{\mathrm{Ca}} 2.3$, small-conductance $\mathrm{Ca}^{2+}$-sensitive $\mathrm{K}^{+}$channels $\left(\mathrm{SK}_{\mathrm{Ca}}\right.$ ) isoform. PKG, Protein Kinase G; cGMP, cyclic guanosine 3',5'-monophosphate; GTP, guanosine 5'-triphosphate; SR, sarcoplasmic reticulum; IP 3 R, Inositol 1,4,5-trisphosphate receptor; RyR2, type 2 ryanodine receptors; CAMP, Cyclic adenosine monophosphate; PKA, protein kinase A; CGRP, Calcitonin gene-related peptide; CGRP receptor, Calcitonin gene-related peptide receptor; CICR, calcium-induced calcium release; LELs, late endosomes and lysosomes; $\mathrm{H}_{2} \mathrm{O}_{2}$, Hydrogen peroxide.

authors speculated that TRPV1 channels directly regulate MBF and impairment of TRPV1 channels could contribute to vascular dysfunction that is typically observed in diabetes. As previously described, lowering $\mathrm{pH}$ is a stimulus for TRPV1 activation. The study by Guarini et al. (2012) demonstrates a possible desensitization of TRPV1 in situations of prolonged acidic environment exposure. Further investigation into prolonged acidic environment on TRPV1 desensitization is necessary.

A follow-up study by this group reported that acute $\mathrm{H}_{2} \mathrm{O}_{2}$ exposure potentiated capsaicin-mediated coronary blood flow (CBF), using the same methodology that was described by Guarini et al. (2012), responses and capsaicin-induced dilation of coronary microvessels in control mice, but $\mathrm{H}_{2} \mathrm{O}_{2}$ had little potentiating effect on capsaicin-mediated responses in $\mathrm{db} / \mathrm{db}$ and TRPV1 knockout mice. However, after excessive $\mathrm{H}_{2} \mathrm{O}_{2}$ exposure, $\mathrm{CBF}$ and microvessel responses in the control mice resembled those of the attenuated responses seen in TRPV1 knockout and $\mathrm{db} / \mathrm{db}$ mice. The author indicated that $\mathrm{H}_{2} \mathrm{O}_{2}$-induced increases in CBF are promoted, in part, by TRPV1 channels. Moreover, prolonged $\mathrm{H}_{2} \mathrm{O}_{2}$ exposure disrupts TRPV1-dependent coronary vascular signaling, which can cause in-tissue perfusion impairments observed in diabetes (DelloStritto et al., 2016).

Sun et al. (2013) demonstrated that cultured endothelial cells that are exposed to a high level of glucose $(30 \mathrm{mmol} / \mathrm{L})$, reduced TRPV1 expression and protein kinase A (PKA) phosphorylation compared with control cells and that these effects were reversed by the administration of capsaicin $(1 \mu \mathrm{mol} / \mathrm{L})$. Similarly, in the aorta and mesenteric arteries from $\mathrm{db} / \mathrm{db}$ mice, TRPV1 expression and PKA phosphorylation were decreased, but uncoupling protein 2 (UCP2) level was significantly higher when compared to wild type mice. After dietary administration of $0.01 \%$ capsaicin for 14 weeks, TRPV1 activation induced PKA phosphorylation and elevated the expression level of UCP2 in diabetic mice. Moreover, capsaicin ameliorated vascular oxidative stress and increased $\mathrm{NO}$ levels in $\mathrm{db} / \mathrm{db}$ mice. The authors concluded that TRPV1 activation by capsaicin might attenuate hyperglycemia-induced endothelial dysfunction through a mechanism involving the PKA and UCP2-mediated antioxidant effect (Sun et al., 2013). If this conclusion is accurate, then it would indicate a possible target for future research on chronic treatment with TRPV1 agonists in the diabetic and obesity conditions, evaluating whether these agonists could attenuate or prevent vascular dysfunction. In addition, these studies demonstrate new possibilities of capsaicin-rich dietary recommendations for complementary assistance in the treatment of diabetic patients.

Similarly, Bratz et al. (2008) demonstrated impaired capsaicininduced vasodilation in coronary arteries from obese Ossabaw swine (diets were provided for 24 weeks; $46 \%$ of total kcal from fat) associated with reduced expression of TRPV1 protein and cation influx into endothelial cells. On the other hand, TRPV1 channel mRNA expression was increased in obese swine compared with lean controls. The authors concluded that TRPV1 channel signaling is diminished in metabolic syndrome and this disrupted pathway can contribute to the endothelial dysfunction and the development of coronary artery disease (Bratz et al., 2008). These findings support the notion that decreased expression of TRPV1 channel and $\mathrm{Ca}^{2+}$ influx into endothelial cells promote insufficient vasodilator response, collaborating to the endothelial dysfunction related to diabetic and obesity conditions.

Together, these studies support a model in which activation of TRPV1 channels from endothelial cells and perivascular sensory nerves cause vasodilation. This mechanism may be disrupted during diabetes and obesity, contributing to vascular dysfunction associated with these conditions, resulting in higher incidence of headaches, coronary disease, and tissue perfusion impairment.

However, Pamarthi et al. (2002) demonstrated that capsaicininduced concentration-dependent relaxation of branch II and III mesenteric arteries and CGRP nerve density was similar in the Zucker diabetic fatty (ZDF) rat, a model of type II diabetes, and genetic controls. ZDF rats exhibit obesity, severe hyperglycemia, an early hyperinsulinemia and dyslipidemia. Moreover, the obesity is promoted by the $f a$ leptin receptor mutation (Pamarthi et al., 2002), but, as described before, this is not common cause of obesity among humans. 
In contrast, Davidson et al. (2006) reported that capsaicin induced a concentration-dependent vasoconstriction of epineural arterioles of the sciatic nerve from Sprague-Dawley rats, concluding that vasoconstriction was likely due to the release of neuropeptide Y (NPY) contained in nerves that innervate these arterioles. However, vasoconstriction to capsaicin was significantly decreased in long-term diabetic rats. This altered response was correlated with the reduced expression of TRPV1 in epineural arterioles in diabetic rats (Davidson et al., 2006). Moreover, the present evidence shows that TRPV1 channels expression and/or activity in sensory nerves that innervate these arterioles are decreased under diabetic condition. Overall, these findings are in accordance with findings reported by Haddock and Hill (2011). In an animal model of obesity, capsaicin $(10 \mu \mathrm{M})$ promoted a significant increase in nerve-mediated vasoconstriction induced by a $10 \mathrm{~Hz}$ stimulation in small mesenteric arteries from groups fed a high-fat (diets started at 6 weeks of age and were provided for 20-24 weeks; containing $43 \%$ of total calories as fat) and normal diet, although the effect was greater in control rats (Haddock and Hill, 2011). From the results, it is clear that common factors between obesity and diabetes can modulate TRPV1 channel, leading to the reduced vasoconstriction. Additional studies to investigate which specific mechanisms collaborate to TRP channels modulation in each disease are necessary.

A study by Ohanyan et al. (2011) showed that capsaicin caused an increase in mean arterial blood pressure (MAP) in mice, but the increase MAP was attenuated in the $\mathrm{db} / \mathrm{db}$ mice. In addition, mice were given the ganglion blocker, hexamethonium, to evaluate the primary actions of capsaicin and to eliminate reflex adjustments. Furthermore, this diminished capsaicin-induced pressor response was correlated with reduced aortic TRPV1 protein expression in $\mathrm{db} / \mathrm{db}$ mice. Moreover, cultured bovine aortic endothelial cells exposed to capsaicin augmented endothelin production and endothelin $\mathrm{A}\left(\mathrm{ET}_{A}\right)$ receptor inhibition reduced the capsaicin-mediated rises in MAP. Based on these findings, the authors indicated that TRPV1 channels are involved in the regulation of vascular reactivity and systemic pressure through production of endothelin, resulting in activation of vascular $\mathrm{ET}_{A}$ receptors. Therefore, a decrease in vascular TRPV1 channel expression may contribute to vascular dysfunction in diabetes. The authors suggest that this reduced TRPV1 channels could promote sensitization of vasoconstrictor pathways and reduced functional hyperemia present in diabetic patients (Ohanyan et al., 2011). A limitation of this study was the use of conductance vessels instead of resistance vessels in order to evaluate TRPV1 protein expression. Moreover, further studies should evaluate if substance P and NPY can participate in the capsaicin-mediated pressor response.

Marshall and colleagues revealed that hypertension and vascular hypertrophy were observed in HFD-fed wild-type (diets for 12 weeks from 3 weeks of age; $35 \%$ fat from lard) but not HFD-fed TRPV1 knockout mice, indicating that the onset of vascular remodeling may have an association between TRPV1 and obesity-induced high blood pressure. Moreover, constrictor and dilator responses to phenylephrine, CGRP, and the endothelium-dependent carbachol remained intact, suggesting little vascular dysfunction in the mesenteric resistance artery in this obese model. Interestingly, the authors provided evidence that TRPV1 knockout mice were protected from obesity-induced hypertension and vascular hypertrophy (Marshall et al., 2013; Table 1). However, it is important to note that these results differ from studies that have linked decreased TRPV1 expression or/and function with a worsened phenotype. Moreover, there is no significant alteration on the mean arterial pressure in TRPV1 knockout mice related to wild-type mice under normal diet. This implies that altered TRPV1 activity can be associated with a compensatory response that counteracts the hypertension in this model of obesity. The HFD-wild-type mice show low-grade inflammation, reducing glucose tolerance and raised levels of adipokine that could be involved with modulation of this channel. Furthermore, it cannot be ruled out that the different influences of TRPV1 channels on the vasculature depend on the tested diabetic or obese animal model. Thus, additional research is needed to confirm these observations.

Collectively, these findings reveal the downregulated TRPV1 channel expression is related to the diabetic condition (Figures 2A,B). In obese animal models, these studies demonstrated alterations in TRPV1 channel expression and/or function, suggesting a role of TRPV1 in obese conditions (Figures 2A,C). Nevertheless, the data obtained from these studies are divergent, which can be justified by the use of different obesity animal models, observed by distinct diet compositions, durations and age of onset of diet intervention, which can result in different metabolic profiles and severity of obesity. In addition to the different models, different vascular beds were utilized which confound the conclusion's coalescence. Overall, these findings demonstrate that mainly TRPV1 channels in endothelial cells and perivascular sensory nerves are altered under diabetic and obese conditions.

\section{The Role of TRPV4 in the Vasculature Under Diabetic and Obese Conditions}

TRPV4 is expressed in the aorta (Gao et al., 2020), mesenteric (Ma et al., 2013), carotid (Hartmannsgruber et al., 2007), pulmonary (Martin et al., 2012), cerebral basilar (Han et al., 2018), and renal (Soni et al., 2017) arteries, among others, and it can be present in both VSMC (Martin et al., 2012; Soni et al., 2017) and the endothelium (Marrelli et al., 2007; Ma et al., 2013; Han et al., 2018). A broad range of stimuli can lead to TRPV4 activation, including heat $\left(>27^{\circ} \mathrm{C}\right.$ ) (Güler et al., 2002; Watanabe et al., 2002b), hypoosmotic conditions (Liedtke et al., 2000; Strotmann et al., 2000; Alessandri-Haber et al., 2003), low pH and citrate (Suzuki et al., 2003), 5,6- epoxyeicosatrienoic acid (Watanabe et al., 2003), and 4- $\alpha$-phorbol esters (Watanabe et al., $2002 a, b)$. TRPV4 is a nonselective cation channel, permeable to $\mathrm{Ca}^{2+}, \mathrm{Mg}^{2+}$ and $\mathrm{K}^{+}$(Voets et al., 2002), and it exhibits moderate permeability to $\mathrm{Ca}^{2+}\left(\mathrm{P}_{\mathrm{Ca}} / \mathrm{P}_{\mathrm{Na}} \sim 6\right)$ (Strotmann et al., 2000; Voets et al., 2002; Watanabe et al., 2002a).

Moreover, there is evidence that TRPV4-mediated stimulation of intermediate-conductance $\mathrm{Ca}^{2+}$-sensitive $\mathrm{K}^{+}$channels $\left(\mathrm{IK}_{\mathrm{Ca}}\right)$ and/or small-conductance $\mathrm{Ca}^{2+}$-sensitive $\mathrm{K}^{+}$channels $\left(\mathrm{SK}_{\mathrm{Ca}}\right)$ channels can promote vasodilation, likely via an EDHF pathway 
(Zhang et al., 2013; Han et al., 2018). For example, there is a functional interaction between TRPV4 and the $\mathrm{K}_{\mathrm{Ca}} 2.3$, $\mathrm{SK}_{\mathrm{Ca}}$ isoform, in endothelial cells (Sonkusare et al., 2012). This association plays a key role in smooth muscle hyperpolarization and relaxation (Ma et al., 2013; Lu et al., 2017; Huang et al., 2019). Additionally, $\mathrm{Ca}^{2+}$ entry through endothelial TRPV4 channels can trigger NO-dependent vasodilation (Köhler et al., 2006; Marziano et al., 2017).

TRPV4 channel expression appears to be altered in diabetic conditions and has a significant impact on the regulation of vascular tone. Ma et al. (2013) were the first to demonstrate evidence of the physical interaction between TRPV4 and $\mathrm{K}_{\mathrm{Ca}} 2.3$ in endothelial cells from the rat mesenteric artery. The expression levels of TRPV4 and $\mathrm{K}_{\mathrm{Ca}} 2.3$ were reduced and TRPV4- $\mathrm{K}_{\mathrm{Ca}} 2.3$ mediated relaxation was impaired in STZ-induced diabetic rats. The authors proposed that the reduced TRPV4- $\mathrm{K}_{\mathrm{Ca}} 2.3$ signaling could be an underlying mechanism for EDHF dysfunction in diabetic rats (Ma et al., 2013).

Similarly, protein expression of endothelial TRPV4 in the retinal vasculature was reduced in STZ-induced diabetic rats compared with age-matched controls. The authors speculated that TRPV4 channel downregulation may contribute to impaired endothelium-dependent relaxation and retinopathy (Monaghan et al., 2015). Similarly, in $\mathrm{db} / \mathrm{db}$ and STZ -induced diabetic C57BLKS/J mice, mRNA and protein levels of TRPV4 were significantly decreased in aortas, indicating that hyperglycemia is a crucial factor for the diminished TRPV4 expression, and impairs the endothelium-dependent vasodilation observed in diabetic mice (Gao et al., 2020).

A recent report demonstrated that diet-induced obesity (diets started at 6 weeks of age and continued until at 20 weeks; $60 \%$ of total kcal from fat) is associated with impaired $\mathrm{Ca}^{2+}$ influx through TRPV4 channels and vasodilation induced by muscarinic stimulation and GSK1016970A (TRPV4 agonist) in resistance mesenteric arteries from mice. Increased activities of inducible nitric oxide synthase (iNOS) and NOX1 enzymes at myoendothelial projections (MEPs) in obese mice produced higher levels of NO and superoxide radicals, resulting in augmented local peroxynitrite formation and subsequent oxidation of the regulatory protein AKAP150, to impair AKAP150-TRPV4 channel signaling at MEPs. Similarly, vasodilation was also weakened in the splenius/temporalis muscle arteries and peroxynitrite causes the impairment of endothelial TRPV4 channel activity in arteries from obese patients. Inhibition of iNOS or lowered peroxynitrite levels may be a strategy to restore TRPV4 channel activity and vasodilation in the obese condition (Ottolini et al., 2020).

In contrast, a HFD mouse model of obesity (diets initiated at age 5 weeks and continued until at age 6 months; $60 \%$ of total calories from fat), the vasodilator function induced by muscarinic stimulation of the endothelium and the underlying endothelial TRPV4 channel-mediated $\mathrm{Ca}^{2+}$ sparklet entry was not affected in resistance mesenteric arteries from obese mice. Vasodilator responses to GSK1016970A were similar between the mice receiving LFD and HFD. Similarly, there was no change in diameter of the pressure constricted arteries from either HFD or LFD mice in response to TRPV4 inhibition
(HC067047). However, these obese animals exhibit $\mathrm{Ca}^{2+}$ spark$\mathrm{BK}_{\mathrm{Ca}}$ dysfunction that can be associated to development of obesity-related hypertension (Greenstein et al., 2020; Table 1). These studies by Ottolini et al. (2020) and Greenstein et al. (2020) have performed similar approaches, using third-order mesenteric arteries pressurized to $80 \mathrm{mmHg}$, and internal diameter was recorded in response to numerous treatments. As an alternative to these contradicting findings, TRPV4 can play a compensatory role aimed at restoring blood pressure in the study by Greenstein et al. (2020) or additional variables such as the duration on diet, genetic drift and discrepancies in the microbiome, can be associated to the differences found in the TRPV4 channel activity.

Taken together, these reports reveal that the downregulated TRPV4 channel expression is related to impaired vasorelaxation in diabetes (Figures 2A,B). In animal models of obesity, studies demonstrated divergent results (Figures 2A,C), Ottolini et al. (2020) evidenced that reduced TRPV4 channels function can contribute to obesity-induced hypertension, while contrarily, a study by Greenstein et al. (2020) showed no alteration in TRPV4 expression and/or activity, therefore obesity had no influence on the endothelial muscarinic/TRPV4 vasodilator pathway. Moreover, these HFD mouse models of obesity have slight difference between duration of diets. Further studies are clearly needed to confirm these findings.

\section{The Potential Role of TRPML1 in the Vasculature Under Diabetic and Obese Conditions}

TRPML is the most recently identified subfamily of TRP (Bargal et al., 2000; Bassi et al., 2000; Sun et al., 2000), consisting of three members, TRPML1, TRPML2, and TRPML3 (Venkatachalam et al., 2006; see review of Samanta et al., 2018). TRPML1 channels are broadly distributed, located in the lung, heart, skeletal muscle, placenta (Bassi et al., 2000), and VSMC (Thakore et al., 2020), among others. TRPML2 is expressed in gliomas (Morelli et al., 2016), lymphoid and myeloid tissues (Lindvall et al., 2005; Samie et al., 2009), and TRPML3 is most abundant in the cochlea, melanocytes in skin hair follicles (Xu et al., 2007), vomeronasal and olfactory receptor neurons (Castiglioni et al., 2011). Moreover, TRPML1 is the only TRPML member present in smooth muscle cells from cerebral and mesenteric arteries (Thakore et al., 2020).

TRPML1 channels are mainly localized to the membranes of late endosomes and lysosomes (LELs) (Pryor et al., 2006; Vergarajauregui and Puertollano, 2006; Dong et al., 2008), and it is permeable to multiple ions including $\mathrm{Ca}^{2+}, \mathrm{Na}^{+}, \mathrm{K}^{+}$(LaPlante et al., 2002), and $\mathrm{Fe}^{2+}$ (Dong et al., 2008). Moreover, this channel is transiently modulated by changes in cytosolic $\mathrm{Ca}^{2+}$ (LaPlante et al., 2002) and phosphatidylinositol 3,5-bisphosphate [PI(3,5)P2] (Dong et al., 2010). TRPML1 channels participate in some cell functions, including autophagy (Scotto Rosato et al., 2019), exocytosis (LaPlante et al., 2006; Samie et al., 2013), membrane trafficking (LaPlante et al., 2004) and $\mathrm{H}^{+}$homeostasis (Soyombo et al., 2006).

Zhang et al. (2006) showed that lysosomes act as a crucial $\mathrm{Ca}^{2+}$ store and play a role in $\mathrm{Ca}^{2+}$ mobilization 
in coronary arterial smooth muscle cells and subsequently, vasoconstriction of coronary arteries. In this way, the lysosomal luminal concentration of $\mathrm{Ca}^{2+}$ is $\sim 0.5 \mathrm{mM}$, which is higher than cytosolic $\mathrm{Ca}^{2+}$ at $\sim 100 \mathrm{nM}$ (Christensen et al., 2002). Additionally, NAADP can selectively provoke $\mathrm{Ca}^{2+}$ signals from a lysosome-related $\mathrm{Ca}^{2+}$ store alone, which can subsequently be augmented by calcium-induced calcium release (CICR) from the sarcoplasmic reticulum/endoplasmic reticulum via the ryanodine receptor (Kinnear et al., 2004). Moreover, TRPML1 can act as a NAADP-sensitive $\mathrm{Ca}^{2+}$ release channel and mediate $\mathrm{Ca}^{2+}$ release in lysosomes from the liver in rats (Zhang and Li, 2007) and from bovine coronary arterial muscle (Zhang et al., 2009).

A recent study by Thakore et al. demonstrated that TRPML1 is closely associated with type 2 ryanodine receptors (RyR2), inducing $\mathrm{Ca}^{2+}$ sparks in native arterial myocytes. Additionally, TRPML1 channels, acting upstream of RyR2s, were crucial in the spontaneous generation of $\mathrm{Ca}^{2+}$ sparks, leading to $\mathrm{BK}_{\mathrm{Ca}}$ channel activity that resulted in membrane hyperpolarization, arterial myocyte relaxation, and vasodilation. Consequently, mice deficient in TRPML1 $\left(M \operatorname{coln} 1^{-/-}\right)$resulted in excessive vasoconstriction and hypertension. The authors concluded that under physiological conditions, TRPML1 channels initiate $\mathrm{Ca}^{2+}$ sparks, thus diminishing myocyte contractility to regulate vascular resistance and blood pressure (Thakore et al., 2020). This work provides unpredicted results that support an unconventional role for TRPML1 channels in arterial smooth muscle cells and hypertension. In this way, we speculated that the TRPML1 channel could have a potential role in the vasculature under diabetic and obese conditions. Further studies are needed to clarify whether TRPML1 activity and/or expression are altered in the vasculature during cardiometabolic disorders, such as obesity and diabetes, so far lacking in the scientific literature.

\section{THE ROLE OF PERIVASCULAR ADIPOSE TISSUE (PVAT) AND REACTIVE OXYGEN SPECIES (ROS) TO THE VASCULAR DYSFUNCTION}

Perivascular adipose tissue is in close proximity with the vasculature, and it surrounds most blood vessels, including aortic (Azul et al., 2020), coronary (Payne et al., 2009), brachial (Rittig et al., 2008) and mesenteric (Fésüs et al., 2007) arteries. PVAT is considered an active endocrine organ, producing and releasing many bioactive signaling molecules, such as: superoxide (Gao et al., 2006), hydrogen peroxide (Gao et al., 2007), tumor necrosis factor- $\alpha$ (TNF- $\alpha$ ) (Virdis et al., 2015), leptin (GálvezPrieto et al., 2012), adiponectin (Meijer et al., 2013), visfatin (Wang et al., 2009), angiotensin (1-7) (Lee et al., 2009), and exosomes (Zhao et al., 2019). Upon secretion into the circulation, these molecules play an important role on vascular function, modulating the vasodilation by endothelium-independent and dependent pathways (Dubrovska et al., 2004; Salcedo et al., 2007; Yamawaki et al., 2009, 2010). In obesity and diabetes, PVAT dysfunction can induce vascular injury by mechanisms that include raised levels of pro-inflammatory cytokines, enhanced oxidative stress, pro-oxidant/antioxidant imbalance (Greenstein et al., 2009; Ketonen et al., 2010; Gil-Ortega et al., 2014; Azul et al., 2020), and a modification in the adipokine secretory profile (Saxton et al., 2019).

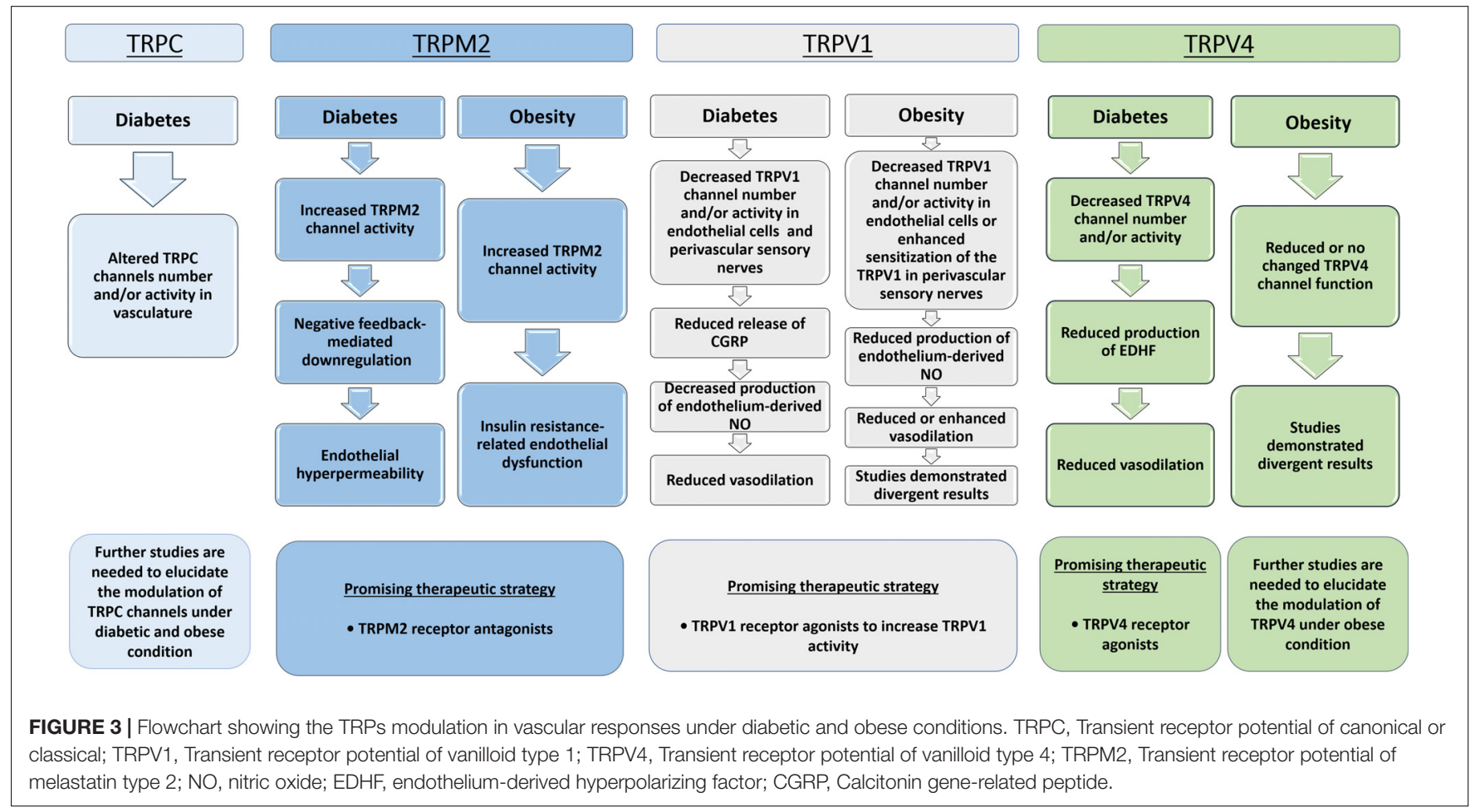


In addition, ROS are generated as a by-product of the cellular oxidative metabolism, and they are reactive molecules containing oxygen such as hydrogen peroxide, superoxide, and hydroxyl radical (Schieber and Chandel, 2014). In physiological levels, ROS play an important role in the regulation of numerous biological events, including proliferation (Arana et al., 2012), and angiogenesis (Wang et al., 2020) whereas excessive ROS (oxidative stress) are involved to several pathological conditions such as obesity (da Costa et al., 2017), and diabetes (Coughlan et al., 2009). As a result, oxidative stress can induce vascular dysfunction, leading reduced NO bioavailability (Cho et al., 2013), elevated peroxynitrite formation, eNOS uncoupling (Gamez-Mendez et al., 2015), and VSMC proliferation (Zhou et al., 2016).

Therefore, PVAT dysfunction and enhanced oxidative stress, present in diabetes and obesity, contribute to vascular damage (Greenstein et al., 2009; Ketonen et al., 2010; Gil-Ortega et al., 2014; Azul et al., 2020). Highlighting that PVAT dysfunction can be source of an abnormal generation of ROS (Ketonen et al., 2010; Azul et al., 2020). However, the literature is scarce to report the direct influences of products from PVAT on the TRP channels, despite oxidative stress modifying the expression and/or activity of the TRP channels. For example, increased oxidative stress promotes overactivation of TRPM2 channel in diabetes (Lu et al., 2014) and obesity (Sun et al., 2019). In contrast, peroxynitrite causes the impairment of endothelial TRPV4 channel activity by oxidation of the regulatory protein A-kinase anchoring protein 150 (AKAP150) (Ottolini et al., 2020).

In addition, levels of leptin are higher in obese individuals than in lean ones, leptin can induce hypertension by enhancing TRPM7 channel expression in the carotid body glomus cells and increasing TRPM7 activity (Shin et al., 2019). Moreover, leptin can stimulate TRPC channel, inducing vasoconstriction in endothelium-denuded pulmonary artery and thoracic aorta (Gomart et al., 2017). However, adipose-derived exosomes can reduce the pulmonary barrier hyperpermeability by inhibiting the TRPV4/Ca ${ }^{2+}$ pathway in HFD-induced obesity (Yu et al., 2020). As well, adiponectin can inhibit the expression of TRPV1 at the central terminals, modulating thermal sensitivity in physiological and neuropathic pain conditions (Sun et al., 2018). Consequently, biologically active compounds secreted by PVAT can modulate TRP channels. Furthermore, the secretory profile of PVAT is altered by obesity and diabetes, this may contribute to vascular dysfunction.

\section{REFERENCES}

Abarca-Gómez, L., Abdeen, Z. A., Hamid, Z. A., Abu-Rmeileh, N. M., AcostaCazares, B., Acuin, C., et al. (2017). Worldwide trends in body-mass index, underweight, overweight, and obesity from 1975 to 2016: a pooled analysis of 2416 population-based measurement studies in 128.9 million children, adolescents, and adults. Lancet 390, 2627-2642.

Alessandri-Haber, N., Yeh, J. J., Boyd, A. E., Parada, C. A., Chen, X., Reichling, D. B., et al. (2003). Hypotonicity induces TRPV4-mediated Nociception in Rat. Neuron 39, 497-511.

Alves-Lopes, R., Neves, K. B., Anagnostopoulou, A., Rios, F. J., Lacchini, S., Montezano, A. C., et al. (2020). Crosstalk between vascular redox and calcium signaling in hypertension involves TRPM2 (Transient Receptor

\section{CONCLUSION}

Robust evidence demonstrated that TRPC, TRPM and TRPV channels are involved in pathophysiological responses in the vasculature of animals with metabolic diseases (Figure 3). These disease mechanisms consist of altered expression or activation of TRP channels leading to impaired vasorelaxation, endothelial hyperpermeability, vascular hypertrophy or elevated contractility. In this context, TRP channels could be potential targets for the development of novel therapies to treat vascular dysfunction related to obesity and diabetes. However, additional investigations are necessary to completely elucidate the pathophysiological aspects of vascular TRP channels in obesity and diabetes. Furthermore, clinical researches are lacking in this area, so further clinical studies in this field are required.

However, there does exist a heterogeneity among the obese and diabetic animal models used in these studies. For instance, the severity of the obesity and the metabolic alterations can vary greatly between genetic versus diet-induced obesity. Moreover, there are differences in relation to the duration and the type of fat-diet consumed. In the same way, these studies demonstrated animal models of type 1 and 2 diabetes with different stages of diabetes. Nevertheless, it remains unclear whether the reported findings, in determined animal models can be attributed to the obese or diabetes state, regardless of the etiology.

\section{AUTHOR CONTRIBUTIONS}

RM drafted the manuscript. RW and DS contributed to conceptualization, review, and editing. All authors contributed to the article and approved the submitted version.

\section{FUNDING}

This study was funded by grants from National Council for Scientific and Technological Development (CNPq), process numbers 233867/2014-7 and 306106/2017-5; Fundação de Amparo à Pesquisa do Estado da Bahia (Fapesb); NIDDK Diacomp Pilot and Feasibly Program.

Potential Melastatin 2) Cation channel. Hypertension 75, 139-149. doi: 10.1161/ HYPERTENSIONAHA.119.13861

Andrei, S. R., Sinharoy, P., Bratz, I. N., and Damron, D. S. (2016). TRPA1 is functionally co-expressed with TRPV1 in cardiac muscle: co-localization at z-discs, costameres and intercalated discs. Channels 10, 395-409. doi: 10.1080/ 19336950.2016.1185579

Arana, L., Gangoiti, P., Ouro, A., Rivera, I.-G., Ordoñez, M., Trueba, M., et al. (2012). Generation of reactive oxygen species (ROS) is a key factor for stimulation of macrophage proliferation by ceramide 1-phosphate. Exp. Cell Res. 318, 350-360. doi: 10.1016/j.yexcr.2011.11.013

Azul, L., Leandro, A., Boroumand, P., Klip, A., Seiça, R., and Sena, C. M. (2020). Increased inflammation, oxidative stress and a reduction in antioxidant defense enzymes in perivascular adipose tissue contribute to vascular dysfunction 
in type 2 diabetes. Free Radic. Biol. Med. 146, 264-274. doi: 10.1016/j. freeradbiomed.2019.11.002

Ärnlöv, J., Ingelsson, E., Sundström, J., and Lind, L. (2010). Impact of body mass index and the metabolic syndrome on the risk of cardiovascular disease and death in middle-aged men. Circulation 121, 230-236. doi: 10.1161/ CIRCULATIONAHA.109.887521

Bargal, R., Avidan, N., Ben-Asher, E., Olender, Z., Zeigler, M., Frumkin, A., et al. (2000). Identification of the gene causing mucolipidosis type IV. Nat. Genet. 26, 118-121. doi: 10.1038/79095

Bassi, M. T., Manzoni, M., Monti, E., Pizzo, M. T., Ballabio, A., and Borsani, G. (2000). Cloning of the gene encoding a novel integral membrane protein, mucolipidin-and identification of the two major founder mutations causing mucolipidosis type IV. Am. J. Hum. Genet. 67, 1110-1120.

Beck, A., Kolisek, M., Bagley, L. A., Fleig, A., Penner, R., Beck, A., et al. (2006). Nicotinic acid adenine dinucleotide phosphate and cyclic ADP-ribose regulate TRPM2 channels in T lymphocytes. FASEB J. 20, 962-964. doi: 10.1096/fj.055538fje

Bhatta, A., Yao, L., Xu, Z., Toque, H. A., Chen, J., Atawia, R. T., et al. (2017). Obesity-induced vascular dysfunction and arterial stiffening requires endothelial cell arginase 1. Cardiovasc. Res. 113, 1664-1676. doi: 10.1093/cvr/ cvx164

Boulay, G., Zhu, X., Peyton, M., Jiang, M., Hurst, R., Stefani, E., et al. (1997). Cloning and expression of a novel mammalian homolog of drosophila transient receptor potential (Trp) involved in calcium entry secondary to activation of receptors coupled by the g q class of G protein. J. Biol. Chem. 272, 29672-29680. doi: $10.1074 /$ jbc.272.47.29672

Boustany-Kari, C. M., Gong, M., Akers, W. S., Guo, Z., and Cassis, L. A. (2007). Enhanced vascular contractility and diminished coronary artery flow in rats made hypertensive from diet-induced obesity. Int. J. Obes. 31, 1652-1659. doi: 10.1038/sj.ijo.0803426

Bratz, I. N., Dick, G. M., Tune, J. D., Edwards, J. M., Neeb, Z. P., Dincer, U. D., et al. (2008). Impaired capsaicin-induced relaxation of coronary arteries in a porcine model of the metabolic syndrome. Am. J. Physiol. Heart Circ. Physiol. 294, 2489-2496. doi: 10.1152/ajpheart.01191.2007

Breyne, J., and Vanheel, B. (2006). Methanandamide hyperpolarizes gastric arteries by stimulation of TRPV1 receptors on perivascular CGRP containing nerves. J. Cardiovasc. Pharmacol. 47, 303-309. doi: 10.1097/01.fjc.0000205053.53 946.10

Bussey, C. E., Withers, S. B., Aldous, R. G., Edwards, G., and Heagerty, A. M. (2016). Obesity-related perivascular adipose tissue damage is reversed by sustained weight loss in the rat. Arterioscler. Thromb. Vasc. Biol. 36, 1377-1385. doi: 10.1161/ATVBAHA.116.307210

Cardillo, C., Campia, U., Bryant, M. B., and Panza, J. A. (2002). Increased activity of endogenous endothelin in patients with type II diabetes mellitus. Circulation 106, 1783-1787. doi: 10.1161/01.CIR.0000032260.01569.64

Carrillo-Larco, R. M., Luza-Dueñas, A. C., Urdániga-Hung, M., and Bernabé-Ortiz, A. (2018). Diagnosis of erectile dysfunction can be used to improve screening for Type 2 diabetes mellitus. Diabet. Med. 35, 1538-1543. doi: 10.1111/dme. 13783

Cassuto, J., Dou, H., Czikora, I., Szabo, A., Patel, V. S., Kamath, V., et al. (2014). Peroxynitrite disrupts endothelial caveolae leading to eNOS uncoupling and diminished flow-mediated dilation in coronary arterioles of diabetic patients. Diabetes 63, 1381-1393. doi: 10.2337/db13-0577

Castiglioni, A. J., Remis, N. N., Flores, E. N., and García-Añoveros, J. (2011). Expression and vesicular localization of mouse Trpml3 in stria vascularis, hair cells, and vomeronasal and olfactory receptor neurons. J. Comp. Neurol. 519, 1095-1114. doi: 10.1002/cne.22554

Caterina, M. J., Leffler, A., Malmberg, A., Martin, W. J., Trafton, J., Petersen-Zeitz, K. R., et al. (2000). Impaired nociception and pain sensation in mice lacking the capsaicin receptor. Science 288, 306-313. doi: 10.1126/science.288.5464.306

Caterina, M. J., Schumacher, M. A., Tominaga, M., Rosen, T. A., Levine, J. D., and Julius, D. (1997). The capsaicin receptor: a heat-activated ion channel in the pain pathway. Nature 389, 816-824. doi: 10.1038/ 39807

Censin, J. C., Peters, S. A. E., Bovijn, J., Ferreira, T., Pulit, S. L., Mägi, R., et al. (2019). Causal relationships between obesity and the leading causes of death in women and men. PLoS Genet. 15:e1008405. doi: 10.1371/journal.pgen.10 08405
Cesare, P., Moriondo, A., Vellani, V., and Mcnaughton, P. A. (1999). Ion channels gated by heat. Proc. Natl. Acad. Sci. U.S.A. 96, 7658-7663. doi: 10.1073/pnas.96. 14.7658

Chen, W., Druhan, L. J., Chen, C. A., Hemann, C., Chen, Y. R., Berka, V., et al. (2010). Peroxynitrite induces destruction of the tetrahydrobiopterin and heme in endothelial nitric oxide synthase: transition from reversible to irreversible enzyme inhibition. Biochemistry 49, 3129-3137. doi: 10.1021/bi9016632

Cheng, H., Beck, A., Launay, P., Gross, S. A., Stokes, A. J., Kinet, J.-P., et al. (2007). TRPM4 controls insulin secretion in pancreatic $\beta$-cells. Cell Calcium 41, 51-61. doi: 10.1016/j.ceca.2006.04.032

Ching, L.-C., Kou, Y. R., Shyue, S.-K., Su, K.-H., Wei, J., Cheng, L.-C., et al. (2011). Molecular mechanisms of activation of endothelial nitric oxide synthase mediated by transient receptor potential vanilloid type 1. Cardiovasc. Res. 91, 492-501. doi: 10.1093/cvr/cvr104

Cho, Y. E., Basu, A., Dai, A., Heldak, M., and Makino, A. (2013). Coronary endothelial dysfunction and mitochondrial reactive oxygen species in type 2 diabetic mice. Am. J. Physiol. Cell Physiol. 305, C1033-C1040. doi: 10.1152/ ajpcell.00234.2013

Christensen, K. A., Myers, J. T., and Swanson, J. A. (2002). pH-dependent regulation of lysosomal calcium in macrophages. J. Cell Sci. 115, 599-607.

Chung, A. W. Y., Yeung, K. A., Chum, E., Okon, E. B., and van Breemen, C. (2009). Diabetes modulates capacitative calcium entry and expression of transient receptor potential canonical channels in human saphenous vein. Eur. J. Pharmacol. 613, 114-118. doi: 10.1016/j.ejphar.2009.04.029

Clapham, D. E., Runnels, L. W., and Strübing, C. (2001). The TRP ion channel family. Nat. Rev. Neurosci. 2, 387-396. doi: 10.1038/35077544

Cosens, D. J., and Manning, A. (1969). Abnormal electroretinogram from a Drosophila mutant. Nature 224, 285-287. doi: 10.1038/224285a0

Coughlan, M. T., Thorburn, D. R., Penfold, S. A., Laskowski, A., Harcourt, B. E., Sourris, K. C., et al. (2009). RAGE-induced cytosolic ROS promote mitochondrial superoxide generation in diabetes. J. Am. Soc. Nephrol. 20, 742-752. doi: 10.1681/ASN.2008050514

Cvetkov, T. L., Huynh, K. W., Cohen, M. R., and Moiseenkova-Bell, V. Y. (2011). Molecular architecture and subunit organization of TRPA1 ion channel revealed by electron microscopy. J. Biol. Chem. 286, 38168-38176. doi: 10.1074/ jbc.M111.288993

Czikora, Á., Lizanecz, E., Bakó, P., Rutkai, I., Ruzsnavszky, F., Magyar, J., et al. (2012). Structure-activity relationships of vanilloid receptor agonists for arteriolar TRPV1. Br. J. Pharmacol. 165, 1801-1812. doi: 10.1111/j.1476-5381. 2011.01645.x

da Costa, R. M., Fais, R. S., Dechandt, C. R. P., Louzada-Junior, P., Alberici, L. C., Lobato, N. S., et al. (2017). Increased mitochondrial ROS generation mediates the loss of the anti-contractile effects of perivascular adipose tissue in high-fat diet obese mice. Br. J. Pharmacol. 174, 3527-3541. doi: 10.1111/bph.13687

Davidson, E. P., Coppey, L. J., and Yorek, M. A. (2006). Activity and expression of the vanilloid receptor 1 (TRPV1) is altered by long-term diabetes in epineurial arterioles of the rat sciatic nerve. Diabetes Metab. Res. Rev. 22, 211-219. doi: 10.1002/dmrr.599

Davis, J. B., Gray, J., Gunthorpe, M. J., Hatcher, J. P., Davey, P. T., Overend, P., et al. (2000). Vanilloid receptor-1 is essential for inflammatory thermal hyperalgesia. Nature 405, 183-187. doi: 10.1038/35012076

DelloStritto, D. J., Connell, P. J., Dick, G. M., Fancher, I. S., Klarich, B., Fahmy, J. N., et al. (2016). Differential regulation of TRPV1 channels by H2O2: implications for diabetic microvascular dysfunction. Basic Res. Cardiol. 111:21.

Dietrich, A., Kalwa, H., and Gudermann, T. (2010). TRPC channels in vascular cell function. Thromb. Haemost. 103, 262-270.

Dietrich, A., Mederos y Schnitzler, M., Gollasch, M., Gross, V., Storch, U., Dubrovska, G., et al. (2005). Increased vascular smooth muscle contractility in TRPC6-/- mice. Mol. Cell. Biol. 25, 6980-6989.

Dong, X., Shen, D., Wang, X., Dawson, T., Li, X., Zhang, Q., et al. (2010). PI(3,5)P2 controls membrane traffic by direct activation of mucolipin $\mathrm{Ca} 2+$ release channels in the endolysosome. Nat. Commun. 1:38. doi: 10.1038/ncomms 1037

Dong, X.-P., Cheng, X., Mills, E., Delling, M., Wang, F., Kurz, T., et al. (2008). The type IV mucolipidosis-associated protein TRPML1 is an endolysosomal iron release channel. Nature 455, 992-996. doi: 10.1038/nature07311

Doupis, J., Rahangdale, S., Gnardellis, C., Pena, S. E., Malhotra, A., and Veves, A. (2011). Effects of diabetes and obesity on vascular reactivity, inflammatory 
cytokines, and growth factors. Obesity 19, 729-735. doi: 10.1038/oby.20 10.193

D'souza, J. M. P., Pamela D'souza, R., Vijin, V. F., Shetty, A., Arunachalam, C., Ramanath Pai, V., et al. (2016). High predictive ability of glycated hemoglobin on comparison with oxidative stress markers in assessment of chronic vascular complications in type 2 diabetes mellitus. Scand. J. Clin. Lab. Invest. 76, 51-57. doi: 10.3109/00365513.2015.1092048

Du, J., Xie, J., and Yue, L. (2009). Modulation of TRPM2 by acidic pH and the underlying mechanisms for $\mathrm{pH}$ sensitivity. J. Gen. Physiol. 134, 471-488. doi: 10.1085/jgp.200910254

Dubrovska, G., Verlohren, S., Luft, F. C., and Gollasch, M. (2004). Mechanisms of ADRF release from rat aortic adventitial adipose tissue. Am. J. Physiol. Circ. Physiol. 286, H1107-H1113. doi: 10.1152/ajpheart.00656.2003

Dux, M., Rosta, J., Pintér, S., Sántha, P., and Jancsó, G. (2007). Loss of capsaicin-induced meningeal neurogenic sensory vasodilatation in diabetic rats. Neuroscience 150, 194-201. doi: 10.1016/j.neuroscience.2007.09.001

Dux, M., Sántha, P., and Jancsó, G. (2003). Capsaicin-sensitive neurogenic sensory vasodilatation in the dura mater of the rat. J. Physiol. 552, 859-867. doi: 10.1113/ jphysiol.2003.050633

Earley, S., and Brayden, J. E. (2015). Transient receptor potential channels in the vasculature. Physiol. Rev. 95, 645-690. doi: 10.1152/physrev.00026.2014

Earley, S., Pauyo, T., Drapp, R., Tavares, M. J., Liedtke, W., and Brayden, J. E. (2009). TRPV4-dependent dilation of peripheral resistance arteries influences arterial pressure. Am. J. Physiol. Circ. Physiol. 297, H1096-H1102. doi: 10.1152/ ajpheart.00241.2009

Einarson, T. R., Acs, A., Ludwig, C., and Panton, U. H. (2018). Prevalence of cardiovascular disease in type 2 diabetes: a systematic literature review of scientific evidence from across the world in 2007-2017. Cardiovasc. Diabetol. 17:83.

Evans, J. F., Lee, J. H., and Ragolia, L. (2009). Ang-II-induced Ca2+ influx is mediated by the $1 / 4 / 5$ subgroup of the transient receptor potential proteins in cultured aortic smooth muscle cells from diabetic Goto-Kakizaki rats. Mol. Cell. Endocrinol. 302, 49-57. doi: 10.1016/j.mce.2008.12.004

Fajarini, I. A., and Sartika, R. A. D. (2019). Obesity as a common Type-2 diabetes comorbidity: eating behaviors and other determinants in Jakarta, Indonesia. Kesmas Natl. Public Heal. J. 13, 157-163. doi: 10.21109/kesmas.v13i4. 2483

Farb, M. G., Tiwari, S., Karki, S., Ngo, D. T. M., Carmine, B., Hess, D. T., et al. (2014). Cyclooxygenase inhibition improves endothelial vasomotor dysfunction of visceral adipose arterioles in human obesity. Obesity 22, 349355. doi: 10.1002/oby.20505

Feng, X., Huang, Y., Lu, Y., Xiong, J., Wong, C.-O., Yang, P., et al. (2014). Drosophila TRPML Forms PI(3,5)P 2 -activated Cation Channels in Both Endolysosomes and Plasma Membrane. J. Biol. Chem. 289, 4262-4272. doi: 10.1074/jbc.M113.506501

Fésüs, G., Dubrovska, G., Gorzelniak, K., Kluge, R., Huang, Y., Luft, F., et al. (2007). Adiponectin is a novel humoral vasodilator. Cardiovasc. Res. 75, 719-727. doi: 10.1016/j.cardiores.2007.05.025

Freichel, M., Suh, S. H., Pfeifer, A., Schweig, U., Trost, C., Weißgerber, P., et al. (2001). Lack of an endothelial store-operated Ca2+ current impairs agonistdependent vasorelaxation in TRP4-/- mice. Nat. Cell Biol. 3, 121-127. doi: $10.1038 / 35055019$

Fujiwara, Y., and Minor, D. L. (2008). X-ray crystal structure of a TRPM assembly domain reveals an antiparallel four-stranded coiled-coil. J. Mol. Biol. 383, 854-870. doi: 10.1016/j.jmb.2008.08.059

Fülöp, P., Seres, I., Lorincz, H., Harangi, M., Somodi, S., and Paragh, G. (2014). Association of chemerin with oxidative stress, inflammation and classical adipokines in non-diabetic obese patients. J. Cell. Mol. Med. 18, 1313-1320. doi: $10.1111 /$ jcmm. 12282

Gálvez-Prieto, B., Somoza, B., Gil-Ortega, M., García-Prieto, C. F., de las Heras, A. I., González, M. C., et al. (2012). Anticontractile effect of perivascular adipose tissue and leptin are reduced in hypertension. Front. Pharmacol. 3:103. doi: 10.3389/fphar.2012.00103

Gamez-Mendez, A. M., Vargas-Robles, H., Ríos, A., and Escalante, B. (2015). Oxidative stress-dependent coronary endothelial dysfunction in obese mice. PLoS One 10:e0138609. doi: 10.1371/journal.pone.01 38609
Gao, G., Bai, X.-Y., Xuan, C., Liu, X.-C., Jing, W.-B., Novakovic, A., et al. (2012). Role of TRPC3 channel in human internal mammary artery. Arch. Med. Res. 43, 431-437. doi: 10.1016/j.arcmed.2012.08.010

Gao, P., Li, L., Wei, X., Wang, M., Hong, Y., Wu, H., et al. (2020). Activation of transient receptor potential channel Vanilloid 4 by DPP-4 (Dipeptidyl Peptidase-4) inhibitor vildagliptin protects against diabetic endothelial dysfunction. Hypertension 75, 150-162. doi: 10.1161/HYPERTENSIONAHA. 119.13778

Gao, Y., Takemori, K., Su, L., An, W., Lu, C., Sharma, A., et al. (2006). Perivascular adipose tissue promotes vasoconstriction: the role of superoxide anion. Cardiovasc. Res. 71, 363-373. doi: 10.1016/j.cardiores.2006.03.013

Gao, Y.-J., Lu, C., Su, L.-Y., Sharma, A. M., and Lee, R. M. K. (2007). Modulation of vascular function by perivascular adipose tissue: the role of endothelium and hydrogen peroxide. Br. J. Pharmacol. 151, 323-331. doi: 10.1038/sj.bjp.07 07228

Garofolo, M., Gualdani, E., Giannarelli, R., Aragona, M., Campi, F., Lucchesi, D., et al. (2019). Microvascular complications burden (nephropathy, retinopathy and peripheral polyneuropathy) affects risk of major vascular events and allcause mortality in type 1 diabetes: a 10 -year follow-up study. Cardiovasc. Diabetol. 18, 159.

Ge, R., Tai, Y., Sun, Y., Zhou, K., Yang, S., Cheng, T., et al. (2009). Critical role of TRPC6 channels in VEGF-mediated angiogenesis. Cancer Lett. 283, 43-51. doi: 10.1016/j.canlet.2009.03.023

Giamarchi, A., Feng, S., Rodat-Despoix, L., Xu, Y., Bubenshchikova, E., Newby, L. J., et al. (2010). A polycystin-2 (TRPP2) dimerization domain essential for the function of heteromeric polycystin complexes. EMBO J. 29, 1176-1191. doi: $10.1038 /$ emboj. 2010.18

Gil-Ortega, M., Condezo-Hoyos, L., García-Prieto, C. F., Arribas, S. M., González, M. C., Aranguez, I., et al. (2014). Imbalance between pro and anti-oxidant mechanisms in perivascular adipose tissue aggravates long-term high-fat dietderived endothelial dysfunction. PLoS One 9:e95312. doi: 10.1371/journal.pone. 0095312

Gomart, S., Gaudreau-Ménard, C., Jespers, P., Dilek, O. G., Hupkens, E., Hanthazi, A., et al. (2017). Leptin-induced endothelium-independent vasoconstriction in thoracic aorta and pulmonary artery of spontaneously hypertensive rats: role of calcium channels and stores. PLoS One 12:e0169205. doi: 10.1371/journal.pone. 0169205

González-Muniesa, P., Mártinez-González, M.-A., Hu, F. B., Després, J.-P., Matsuzawa, Y., Loos, R. J. F., et al. (2017). Obesity. Nat. Rev. Dis. Primers 3:17034. doi: 10.1038/nrdp.2017.34

Gonzalez-Perrett, S., Kim, K., Ibarra, C., Damiano, A. E., Zotta, E., Batelli, M., et al. (2001). Polycystin-2, the protein mutated in autosomal dominant polycystic kidney disease (ADPKD), is a Ca2+-permeable nonselective cation channel. Proc. Natl. Acad. Sci. U.S.A. 98, 1182-1187. doi: 10.1073/pnas.98.3.1182

Greenstein, A. S., Kadir, S. Z. A. S., Csato, V., Sugden, S. A., Baylie, R. A., Eisner, D. A., et al. (2020). Disruption of pressure-induced Ca2+ spark vasoregulation of resistance arteries, rather than endothelial dysfunction, underlies obesity-related hypertension. Hypertension 75, 539-548. doi: 10.1161/ HYPERTENSIONAHA.119.13540

Greenstein, A. S., Khavandi, K., Withers, S. B., Sonoyama, K., Clancy, O., Jeziorska, M., et al. (2009). Local inflammation and hypoxia abolish the protective anticontractile properties of perivascular fat in obese patients. Circulation 119, 1661-1670. doi: 10.1161/CIRCULATIONAHA.108.821181

Groschner, K., Hingel, S., Lintschinger, B., Balzer, M., Romanin, C., Zhu, X., et al. (1998). Trp proteins form store-operated cation channels in human vascular endothelial cells. FEBS Lett. 437, 101-106.

Guarini, G., Ohanyan, V. A., Kmetz, J. G., DelloStritto, D. J., Thoppil, R. J., Thodeti, C. K., et al. (2012). Disruption of TRPV1-mediated coupling of coronary blood flow to cardiac metabolism in diabetic mice: role of nitric oxide and BK channels. Am. J. Physiol. Circ. Physiol. 303, H216-H223. doi: 10.1152/ajpheart. 00011.2012

Güler, A. D., Lee, H., Iida, T., Shimizu, I., Tominaga, M., and Caterina, M. (2002). Heat-evoked activation of the ion channel, TRPV4. J. Neurosci. 22, 6408-6414. doi: 10.1523/JNEUROSCI.22-15-06408.2002

Haddock, R. E., and Hill, C. E. (2011). Sympathetic overdrive in obesity involves purinergic hyperactivity in the resistance vasculature. J. Physiol. 589, 32893307. doi: 10.1113/jphysiol.2011.207944 
Hales, C. M., Carroll, M. D., Fryar, C. D., and Ogden, C. L. (2020). Prevalence of obesity and severe obesity among adults: united states, 2017-2018. NCHS Data Brief. 360, 1-8.

Hamdollah Zadeh, M. A., Glass, C. A., Magnussen, A., Hancox, J. C., and Bates, D. O. (2008). VEGF-mediated elevated intracellular calcium and angiogenesis in human microvascular endothelial cells in vitro are inhibited by dominant negative TRPC6. Microcirculation 15, 605-614. doi: 10.1080/ 10739680802220323

Han, J., Xu, H.-H., Chen, X.-L., Hu, H.-R., Hu, K.-M., Chen, Z.-W., et al. (2018). Total Flavone of rhododendron improves cerebral ischemia injury by activating vascular TRPV4 to induce endothelium-derived hyperpolarizing factormediated responses. Evid. Based Complement. Altern. Med. 2018:8919867. doi: $10.1155 / 2018 / 8919867$

Hara, Y., Wakamori, M., Ishii, M., Maeno, E., Nishida, M., Yoshida, T., et al. (2002). LTRPC2 Ca2+-permeable channel activated by changes in redox status confers susceptibility to cell death. Mol. Cell 9, 163-173.

Hartmannsgruber, V., Heyken, W.-T., Kacik, M., Kaistha, A., Grgic, I., Harteneck, C., et al. (2007). Arterial response to shear stress critically depends on endothelial TRPV4 expression. PLoS One 2:e827. doi: 10.1371/journal.pone. 0000827

Hecquet, C., and Malik, A. (2009). Role of H2O2-activated TRPM2 calcium channel in oxidant-induced endothelial injury. Thromb. Haemost. 101, 619-625.

Hecquet, C. M., Ahmmed, G. U., Vogel, S. M., and Malik, A. B. (2008). Role of TRPM2 channel in mediating $\mathrm{H} 2 \mathrm{O} 2$-induced $\mathrm{Ca} 2+$ entry and endothelial hyperpermeability. Circ. Res. 102, 347-355. doi: 10.1161/CIRCRESAHA.107. 160176

Hecquet, C. M., Zhang, M., Mittal, M., Vogel, S. M., Di, A., Gao, X., et al. (2014). Cooperative interaction of trp Melastatin Channel Transient Receptor Potential (TRPM2) with its splice variant TRPM2 short variant is essential for endothelial cell apoptosis. Circ. Res. 114, 469-479. doi: 10.1161/CIRCRESAHA.114.302414

Heiner, I., Eisfeld, J., Halaszovich, C. R., Wehage, E., Jüngling, E., Zitt, C., et al. (2003). Expression profile of the transient receptor potential (TRP) family in neutrophil granulocytes: evidence for currents through long TRP channel 2 induced by ADP-ribose and NAD. Biochem. J. 371, 1045-1053. doi: 10.1042/ bj20021975

Hex, N., Bartlett, C., Wright, D., Taylor, M., and Varley, D. (2012). Estimating the current and future costs of Type 1 and Type 2 diabetes in the UK, including direct health costs and indirect societal and productivity costs. Diabet. Med. 29, 855-862. doi: 10.1111/j.1464-5491.2012.03698.x

Hof, T., Chaigne, S., Récalde, A., Sallé, L., Brette, F., and Guinamard, R. (2019). Transient receptor potential channels in cardiac health and disease. Nat. Rev. Cardiol. 16, 344-360.

Hofmann, T., Schaefer, M., Schultz, G., and Gudermann, T. (2002). Subunit composition of mammalian transient receptor potential channels in living cells. Proc. Natl. Acad. Sci. U.S.A. 99, 7461-7466. doi: 10.1073/pnas.102596199

Hogikyan, R. V., Galecki, A. T., Halter, J. B., and Supiano, M. A. (1999). Heightened norepinephrine-mediated vasoconstriction in type 2 diabetes. Metabolism 48, 1536-1541.

Huang, J., Zhang, H., Tan, X., Hu, M., and Shen, B. (2019). Exercise restores impaired endothelium-derived hyperpolarizing factor-mediated vasodilation in aged rat aortic arteries via the TRPV4-KCa2.3 signaling complex. Clin. Interv. Aging 14, 1579-1587. doi: 10.2147/CIA.S220283

Huang, J.-H., He, G.-W., Xue, H.-M., Yao, X.-Q., Liu, X.-C., Underwood, M. J., et al. (2011). TRPC3 channel contributes to nitric oxide release: significance during normoxia and hypoxia-reoxygenation. Cardiovasc. Res. 91, 472-482. doi: $10.1093 / \mathrm{cvr} / \mathrm{cvr} 102$

Inoue, R., Jensen, L. J., Jian, Z., Shi, J., Hai, L., Lurie, A. I., et al. (2009). Synergistic activation of vascular TRPC6 channel by receptor and mechanical stimulation via phospholipase C/diacylglycerol and phospholipase A2/ $\omega$-Hydroxylase/20HETE Pathways. Circ. Res. 104, 1399-1409. doi: 10.1161/CIRCRESAHA.108. 193227

International Diabetes Federation (2019). IDF Diabetes Atlas, 9th Edn. Brussels: IDF.

Itsuki, K., Imai, Y., Hase, H., Okamura, Y., Inoue, R., and Mori, M. X. (2014). PLCmediated PI $(4,5) \mathrm{P} 2$ hydrolysis regulates activation and inactivation of TRPC6/7 channels. J. Gen. Physiol. 143, 183-201. doi: 10.1085/jgp.201311033
Janssens, A., Gees, M., Toth, B. I., Ghosh, D., Mulier, M., Vennekens, R., et al. (2016). Definition of two agonist types at the mammalian cold-activated channel TRPM8. eLife 5:e17240. doi: 10.7554/eLife.17240

Jian, M.-Y., King, J. A., Al-Mehdi, A.-B., Liedtke, W., and Townsley, M. I. (2008). High vascular pressure-induced lung injury requires P450 epoxygenasedependent activation of TRPV4. Am. J. Respir. Cell Mol. Biol. 38, 386-392. doi: 10.1165/rcmb.2007-0192OC

Johnson, C. D., Melanaphy, D., Purse, A., Stokesberry, S. A., Dickson, P., and Zholos, A. V. (2009). Transient receptor potential melastatin 8 channel involvement in the regulation of vascular tone. Am. J. Physiol. Circ. Physiol. 296, H1868-H1877. doi: 10.1152/ajpheart.01112.2008

Johnson, F. K., Peyton, K. J., Liu, X., Azam, M. A., Shebib, A. R., Johnson, R. A., et al. (2015). Arginase promotes endothelial dysfunction and hypertension in obese rats. Obesity 23, 383-390. doi: 10.1002/oby.20969

Kark, T., Bagi, Z., Lizanecz, E., Pásztor, E. T., Erdei, N., Czikora, Á., et al. (2008). Tissue-specific regulation of microvascular diameter: opposite functional roles of neuronal and smooth muscle located vanilloid receptor-1. Mol. Pharmacol. 73, 1405-1412. doi: 10.1124/mol.107.043323

Kashio, M., Sokabe, T., Shintaku, K., Uematsu, T., Fukuta, N., and Kobayashi, N. (2012). Redox signal-mediated sensitization of transient receptor potential melastatin 2 (TRPM2) to temperature affects macrophage functions. Proc. Natl. Acad. Sci. U.S.A. 109, 6745-6750. doi: 10.1073/pnas.1114193109

Kashio, M., and Tominaga, M. (2017). The TRPM2 channel: a thermo-sensitive metabolic sensor. Channels 11, 426-433. doi: 10.1080/19336950.2017.13 44801

Ketonen, J., Shi, J., Martonen, E., and Mervaala, E. (2010). Periadventitial adipose tissue promotes endothelial dysfunction via oxidative stress in diet-induced obese C57Bl/6 mice. Circ. J. 74, 1479-1487.

Kichko, T. I., Neuhuber, W., Kobal, G., and Reeh, P. W. (2018). The roles of TRPV1, TRPA1 and TRPM8 channels in chemical and thermal sensitivity of the mouse oral mucosa. Eur. J. Neurosci. 47, 201-210. doi: 10.1111/ejn.13799

Kinnear, N. P., Boittin, F.-X., Thomas, J. M., Galione, A., and Evans, A. M. (2004). Lysosome-sarcoplasmic reticulum junctions. J. Biol. Chem. 279, 54319-54326. doi: 10.1074/jbc.M406132200

Kochukov, M. Y., Balasubramanian, A., Abramowitz, J., Birnbaumer, L., and Marrelli, S. P. (2014). Activation of endothelial transient receptor potential C3 channel is required for small conductance calcium-activated potassium channel activation and sustained endothelial hyperpolarization and vasodilation of cerebral artery. J. Am. Heart Assoc. 3:e000913. doi: 10.1161/JAHA.114. 000913

Kosiborod, M., Gomes, M. B., Nicolucci, A., Pocock, S., Rathmann, W., Shestakova, M. V., et al. (2018). Vascular complications in patients with type 2 diabetes: prevalence and associated factors in 38 countries (the DISCOVER study program). Cardiovasc. Diabetol. 17:150. doi: 10.1186/s12933-018-0787-8

Kouidrat, Y., Pizzol, D., Cosco, T., Thompson, T., Carnaghi, M., Bertoldo, A., et al. (2017). High prevalence of erectile dysfunction in diabetes: a systematic review and meta-analysis of 145 studies. Diabet. Med. 34, 1185-1192. doi: 10.1111/dme. 13403

Köhler, R., Heyken, W.-T., Heinau, P., Schubert, R., Si, H., Kacik, M., et al. (2006). Evidence for a functional role of endothelial transient receptor potential V4 in shear stress-induced vasodilatation. Arterioscler. Thromb. Vasc. Biol. 26, 1495-1502. doi: 10.1161/01.ATV.0000225698.36212.6a

Kraft, R., Grimm, C., Grosse, K., Hoffmann, A., Sauerbruch, S., Kettenmann, H., et al. (2004). Hydrogen peroxide and ADP-ribose induce TRPM2-mediated calcium influx and cation currents in microglia. Am. J. Physiol. Cell Physiol. 286, C129-C137. doi: 10.1152/ajpcell.00331.2003

$\mathrm{Ku}, \mathrm{S} . \mathrm{-K}$., and Bae, J.-S. (2016). Vicenin-2 and scolymoside inhibit high-glucoseinduced vascular inflammation in vitro and in vivo. Can. J. Physiol. Pharmacol. 94, 287-295. doi: 10.1139/cjpp-2015-0215

Kwan, H.-Y., Shen, B., Ma, X., Kwok, Y.-C., Huang, Y., Man, Y.-B., et al. (2009). TRPC1 associates with BKCa channel to form a signal complex in vascular smooth muscle cells. Circ. Res. 104, 670-678. doi: 10.1161/CIRCRESAHA.108. 188748

La Favor, J. D., Dubis, G. S., Yan, H., White, J. D., Nelson, M. A. M., Anderson, E. J., et al. (2016). Microvascular endothelial dysfunction in sedentary, obese humans is mediated by NADPH oxidase. Arterioscler. Thromb. Vasc. Biol. 36, 2412-2420. doi: 10.1161/ATVBAHA.116.308339 
Lange, I., Penner, R., Fleig, A., and Beck, A. (2008). Synergistic regulation of endogenous TRPM2 channels by adenine dinucleotides in primary human neutrophils. Cell Calcium 44, 604-615. doi: 10.1016/j.ceca.2008.05.001

LaPlante, J. M., Falardeau, J., Sun, M., Kanazirska, M., Brown, E. M., Slaugenhaupt, S. A., et al. (2002). Identification and characterization of the single channel function of human mucolipin-1 implicated in mucolipidosis type IV, a disorder affecting the lysosomal pathway. FEBS Lett. 532, 183-187. doi: 10.1016/S00145793(02)03670-0

LaPlante, J. M., Sun, M., Falardeau, J., Dai, D., Brown, E. M., Slaugenhaupt, S. A., et al. (2006). Lysosomal exocytosis is impaired in mucolipidosis type IV. Mol. Genet. Metab. 89, 339-348. doi: 10.1016/j.ymgme.2006.05.016

LaPlante, J. M., Ye, C. P., Quinn, S. J., Goldin, E., Brown, E. M., Slaugenhaupt, S. A., et al. (2004). Functional links between mucolipin-1 and $\mathrm{Ca} 2+$-dependent membrane trafficking in mucolipidosis IV. Biochem. Biophys. Res. Commun. 322, 1384-1391. doi: 10.1016/j.bbrc.2004.08.045

Lee, B., Hong, S.-E., Lim, H.-H., Kim, D. H., and Park, C. (2011). Alteration of the transcriptional profile of human embryonic kidney cells by transient overexpression of mouse TRPM7 channels. Cell. Physiol. Biochem. 27, 313-326. doi: $10.1159 / 000327958$

Lee, E., Jung, D. Y., Kim, J. H., Patel, P. R., Hu, X., Lee, Y., et al. (2015). Transient receptor potential vanilloid type-1 channel regulates diet-induced obesity, insulin resistance, and leptin resistance. FASEB J. 29, 3182-3192. doi: 10.1096/fj.14-268300

Lee, R. M. K. W., Lu, C., Su, L.-Y., and Gao, Y.-J. (2009). Endothelium-dependent relaxation factor released by perivascular adipose tissue. J. Hypertens. 27, 782-790. doi: 10.1097/HJH.0b013e328324ed86

Liedtke, W., Choe, Y., Martí-Renom, M. A., Bell, A. M., Denis, C. S., Šali, A., et al. (2000). Vanilloid receptor-related osmotically activated channel (VR-OAC), a candidate vertebrate osmoreceptor. Cell 103, 525-535. doi: 10.1016/S00928674(00)00143-4

Lindvall, J. M., Blomberg, K. E. M., Wennborg, A., and Smith, C. I. E. (2005). Differential expression and molecular characterisation of Lmo7, Myole, Sash1, and Mcoln2 genes in Btk-defective B-cells. Cell. Immunol. 235, 46-55. doi: 10.1016/j.cellimm.2005.07.001

Litwak, L., Goh, S.-Y., Hussein, Z., Malek, R., Prusty, V., and Khamseh, M. E. (2013). Prevalence of diabetes complications in people with type 2 diabetes mellitus and its association with baseline characteristics in the multinational Alchieve study. Diabetol. Metab. Syndr. 5:57. doi: 10.1186/1758-5996-5-57

Liu, S., Qu, M., Ren, W., Hu, H., Gao, N., Wang, G.-D., et al. (2008). Differential expression of canonical (classical) transient receptor potential channels in guinea pig enteric nervous system. J. Comp. Neurol. 511, 847-862. doi: 10.1002/ cne. 21874

Lobato, N. S., Filgueira, F. P., Prakash, R., Giachini, F. R., Ergul, A., Carvalho, M. H. C., et al. (2013). Reduced endothelium-dependent relaxation to anandamide in mesenteric arteries from young obese Zucker rats. PLoS One 8:e63449. doi: 10.1371/journal.pone.0063449

Lu, S., Xiang, L., Clemmer, J. S., Mittwede, P. N., and Hester, R. L. (2014). Oxidative stress increases pulmonary vascular permeability in diabetic rats through activation of transient receptor potential Melastatin 2 (TRPM2) Channels. Microcirculation 21, 754-760. doi: 10.1111/micc.12158

Lu, T., Wang, X. L., Chai, Q., Sun, X., Sieck, G. C., Katusic, Z. S., et al. (2017). Role of the endothelial caveolae microdomain in shear stress-mediated coronary vasorelaxation. J. Biol. Chem. 292, 19013-19023. doi: 10.1074/jbc.M117.786152

Lubomirov, L. T., Gagov, H., Schroeter, M. M., Wiesner, R. J., and Franko, A. (2019). Augmented contractility of murine femoral arteries in a streptozotocin diabetes model is related to increased phosphorylation of MYPT1. Physiol. Rep. 7:e13975. doi: 10.14814/phy2.13975

Ma, L., Ma, S., He, H., Yang, D., Chen, X., Luo, Z., et al. (2010). Perivascular fat-mediated vascular dysfunction and remodeling through the AMPK/mTOR pathway in high-fat diet-induced obese rats. Hypertens. Res. 33, 446-453. doi: 10.1038/hr.2010.11

Ma, X., Du, J., Zhang, P., Deng, J., Liu, J., Lam, F. F.-Y., et al. (2013). Functional Role of TRPV4-K Ca 2.3 signaling in vascular endothelial cells in normal and streptozotocin-induced diabetic rats. Hypertension 62, 134-139. doi: 10.1161/ HYPERTENSIONAHA.113.01500

Marche, P., Dubois, S., Abraham, P., Parot-Schinkel, E., Gascoin, L., HumeauHeurtier, A., et al. (2017). Neurovascular microcirculatory vasodilation mediated by C-fibers and Transient receptor potential vanilloid-type- 1 channels
(TRPV 1) is impaired in type 1 diabetes. Sci. Rep. 7:44322. doi: 10.1038/ srep44322

Marics, B., Peitl, B., Pázmándi, K., Bácsi, A., Németh, J., Oszlács, O., et al. (2017). Diet-induced obesity enhances TRPV1-mediated neurovascular reactions in the Dura Mater. Headache 57, 441-454. doi: 10.1111/head.13033

Marrelli, S. P., O’Neil, R. G., Brown, R. C., and Bryan, R. M. (2007). PLA2 and TRPV4 channels regulate endothelial calcium in cerebral arteries. Am.J. Physiol. Circ. Physiol. 292, H1390-H1397. doi: 10.1152/ajpheart.01006.2006

Marshall, N. J., Liang, L., Bodkin, J., Dessapt-Baradez, C., Nandi, M., CollotTeixeira, S., et al. (2013). A role for TRPV1 in influencing the onset of cardiovascular disease in obesity. Hypertension 61, 246-252. doi: 10.1161/ HYPERTENSIONAHA.112.201434

Martin, E., Dahan, D., Cardouat, G., Gillibert-Duplantier, J., Marthan, R., Savineau, J.-P., et al. (2012). Involvement of TRPV1 and TRPV4 channels in migration of rat pulmonary arterial smooth muscle cells. Pflügers Arch. 464, 261-272. doi: 10.1007/s00424-012-1136-5

Marziano, C., Hong, K., Cope, E. L., Kotlikoff, M. I., Isakson, B. E., and Sonkusare, S. K. (2017). Nitric oxide-dependent feedback loop regulates transient receptor potential Vanilloid 4 (TRPV4) channel cooperativity and endothelial function in small pulmonary arteries. J. Am. Heart Assoc. 6:e007157. doi: 10.1161/JAHA. 117.007157

Mason, R. P., Jacob, R. F., Kubant, R., Walter, M. F., Bellamine, A., Jacoby, A., et al. (2011). Effect of enhanced glycemic control with saxagliptin on endothelial nitric oxide release and CD40 levels in obese rats. J. Atheroscler. Thromb. 18, 774-783. doi: 10.5551/jat.7666

Mathar, I., Vennekens, R., Meissner, M., Kees, F., Van der Mieren, G., Camacho Londoño, J. E., et al. (2010). Increased catecholamine secretion contributes to hypertension in TRPM4-deficient mice. J. Clin. Invest. 120, 3267-3279. doi: 10.1172/JCI41348

Matsumoto, T., Watanabe, S., Taguchi, K., and Kobayashi, T. (2014). Mechanisms underlying increased serotonin-induced contraction in carotid arteries from chronic type 2 diabetic Goto-Kakizaki rats. Pharmacol. Res. 87, 123-132. doi: 10.1016/j.phrs.2014.07.001

Matta, J. A., and Ahern, G. P. (2007). Voltage is a partial activator of rat thermosensitive TRP channels. J. Physiol. 585, 469-482. doi: 10.1113/jphysiol. 2007.144287

Mäkimattila, S., Virkamäki, A., Groop, P.-H., Cockcroft, J., Utriainen, T., Fagerudd, J., et al. (1996). Chronic hyperglycemia impairs endothelial function and insulin sensitivity via different mechanisms in insulin-dependent diabetes mellitus. Circulation 94, 1276-1282. doi: 10.1161/01.CIR.94.6.1276

McHugh, D., Flemming, R., Xu, S.-Z., Perraud, A.-L., and Beech, D. J. (2003). Critical intracellular Ca2+ dependence of transient receptor potential melastatin 2 (TRPM2) cation channel activation. J. Biol. Chem. 278, 1100211006. doi: 10.1074/jbc.M210810200

McKemy, D. D., Neuhausser, W. M., and Julius, D. (2002). Identification of a cold receptor reveals a general role for TRP channels in thermosensation. Nature 416, 52-58. doi: 10.1038/nature719

Mederos y Schnitzler, M., Gudermann, T., and Storch, U. (2018). Emerging roles of diacylglycerol-sensitive TRPC4/5 channels. Cells 7:218. doi: 10.3390/ cells7110218

Meijer, R. I., Bakker, W., Alta, C.-L. A. F., Sipkema, P., Yudkin, J. S., Viollet, B., et al. (2013). Perivascular adipose tissue control of insulin-induced vasoreactivity in muscle is impaired in $\mathrm{db} / \mathrm{db}$ mice. Diabetes 62, 590-598. doi: $10.2337 / \mathrm{db} 11$ 1603

Minke, B., Wu, C.-F., and Pak, W. L. (1975). Induction of photoreceptor voltage noise in the dark in Drosophila mutant. Nature 258, 84-87. doi: 10.1038/ $258084 \mathrm{a} 0$

Mita, M., Ito, K., Taira, K., Nakagawa, J. I., Walsh, M. P., and Shoji, M. (2010). Attenuation of store-operated $\mathrm{Ca} 2+$ entry and enhanced expression of TRPC channels in caudal artery smooth muscle from Type 2 diabetic Goto-Kakizaki rats. Clin. Exp. Pharmacol. Physiol. 37, 670-678. doi: 10.1111/j.1440-1681.2010. 05373.x

Mochizuki, T., Wu, G., Hayashi, T., Xenophontos, S. L., Veldhuisen, B., Saris, J. J., et al. (1996). PKD2, a gene for polycystic kidney disease that encodes an integral membrane protein. Science 272, 1339-1342. doi: 10.1126/science.272. 5266.1339

Monaghan, K., McNaughten, J., McGahon, M. K., Kelly, C., Kyle, D., Yong, P. H., et al. (2015). Hyperglycemia and diabetes downregulate the functional 
expression of TRPV4 channels in retinal microvascular endothelium. PLoS One 10:e0128359. doi: 10.1371/journal.pone.0128359

Montell, C. (2005). The TRP superfamily of cation channels. Sci. Signal. 2005:re3. doi: 10.1126/stke.2722005re3

Montell, C., and Rubin, G. M. (1989). Molecular characterization of the drosophila trp locus: a putative integral membrane protein required for phototransduction. Neuron 2, 1313-1323. doi: 10.1016/0896-6273(89) 90069-X

Morelli, M. B., Nabissi, M., Amantini, C., Tomassoni, D., Rossi, F., Cardinali, C., et al. (2016). Overexpression of transient receptor potential mucolipin-2 ion channels in gliomas: role in tumor growth and progression. Oncotarget 7 , 43654-43668. doi: 10.18632/oncotarget.9661

Nassar, T., Kadery, B., Lotan, C., Da'as, N., Kleinman, Y., and Haj-Yehia, A. (2002). Effects of the superoxide dismutase-mimetic compound tempol on endothelial dysfunction in streptozotocin-induced diabetic rats. Eur. J. Pharmacol. 436, 111-118. doi: 10.1016/S0014-2999(01)01566-7

Nathan, D. M., Barret-Connor, E., Crandall, J. P., Edelstein, S. L., Goldberg, R. B., Horton, E. S., et al. (2015). Long-term effects of lifestyle intervention or metformin on diabetes development and microvascular complications over 15-year follow-up: the Diabetes Prevention Program Outcomes Study. Lancet Diabetes Endocrinol. 3, 866-875. doi: 10.1016/S2213-8587(15)00291-0

Ohanyan, V. A., Guarini, G., Thodeti, C. K., Talasila, P. K., Raman, P., Haney, R. M., et al. (2011). Endothelin-mediated in vivo pressor responses following TRPV1 activation. Am. J. Physiol. Circ. Physiol. 301, H1135-H1142. doi: 10. 1152/ajpheart.00082.2011

Oltman, C. L., Richou, L. L., Davidson, E. P., Coppey, L. J., Lund, D. D., and Yorek, M. A. (2006). Progression of coronary and mesenteric vascular dysfunction in Zucker obese and Zucker diabetic fatty rats. Am. J. Physiol. Circ. Physiol. 291, H1780-H1787. doi: 10.1152/ajpheart.01297.2005

Ottolini, M., Hong, K., Cope, E. L., Daneva, Z., DeLalio, L. J., Sokolowski, J. D., et al. (2020). Local peroxynitrite impairs endothelial transient receptor potential vanilloid 4 channels and elevates blood pressure in obesity. Circulation 141, 1318-1333. doi: 10.1161/CIRCULATIONAHA.119.043385

Pamarthi, M. F., Rudd, M. A., and Bukoski, R. D. (2002). Normal perivascular sensory dilator nerve function in arteries of Zucker diabetic fatty rats. Am. J. Hypertens. 15, 310-315. doi: 10.1016/S0895-7061(01)02334-2

Panagiotakos, D. B., Pitsavos, C., Yannakoulia, M., Chrysohoou, C., and Stefanadis, C. (2005). The implication of obesity and central fat on markers of chronic inflammation: the ATTICA study. Atherosclerosis 183, 308-315. doi: 10.1016/ j.atherosclerosis.2005.03.010

Pandey, K. B., Mishra, N., and Rizvi, S. I. (2010). Protein oxidation biomarkers in plasma of type 2 diabetic patients. Clin. Biochem. 43, 508-511. doi: 10.1016/j. clinbiochem.2009.11.011

Paria, B. C., Vogel, S. M., Ahmmed, G. U., Alamgir, S., Shroff, J., Malik, A. B., et al. (2004). Tumor necrosis factor- $\alpha$-induced TRPC1 expression amplifies storeoperated Ca $2+$ influx and endothelial permeability. Am. J. Physiol. Cell. Mol. Physiol. 287, L1303-L1313. doi: 10.1152/ajplung.00240.2004

Patel, A., MacMahon, S., Chalmers, J., Neal, B., Billot, L., Woodward, M., et al. (2008). Intensive blood glucose control and vascular outcomes in patients with type 2 diabetes. N. Engl. J. Med. 358, 2560-2572. doi: 10.1056/NEJMoa08 02987

Payne, G. A., Bohlen, H. G., Dincer, Ü. D., Borbouse, L., and Tune, J. D. (2009). Periadventitial adipose tissue impairs coronary endothelial function via PKC$\beta$-dependent phosphorylation of nitric oxide synthase. Am. J. Physiol. Circ. Physiol. 297, H460-H465. doi: 10.1152/ajpheart.00116.2009

Peppiatt-Wildman, C. M., Albert, A. P., Saleh, S. N., and Large, W. A. (2007). Endothelin-1 activates a Ca $2+$-permeable cation channel with TRPC3 and TRPC7 properties in rabbit coronary artery myocytes. J. Physiol. 580, 755-764. doi: $10.1113 /$ jphysiol.2006.126656

Perraud, A.-L., Fleig, A., Dunn, C. A., Bagley, L. A., Launay, P., Schmitz, C., et al. (2001). ADP-ribose gating of the calcium-permeable LTRPC2 channel revealed by Nudix motif homology. Nature 411, 595-599. doi: 10.1038/35079100

Pórszász, R., Porkoláb, Á., Ferencz, A., Pataki, T., Szilvássy, Z., and Szolcsányi, J. (2002). Capsaicin-induced nonneural vasoconstriction in canine mesenteric arteries. Eur. J. Pharmacol. 441, 173-175. doi: 10.1016/S0014-2999(01)01596-5

Pryor, P. R., Reimann, F., Gribble, F. M., and Luzio, J. P. (2006). Mucolipin-1 is a lysosomal membrane protein required for intracellular lactosylceramide traffic. Traffic 7, 1388-1398. doi: 10.1111/j.1600-0854.2006.00475.x
Putney, J. W. (2005). Physiological mechanisms of TRPC activation. Pflügers Arch. 451, 29-34. doi: 10.1007/s00424-005-1416-4

Qian, Q., Hunter, L. W., Du, H., Ren, Q., Han, Y., and Sieck, G. C. (2007). Pkd2 +/- vascular smooth muscles develop exaggerated vasocontraction in response to phenylephrine stimulation. J. Am. Soc. Nephrol. 18, 485-493. doi: 10.1681/ ASN.2006050501

Qu, Y.-Y., Wang, L.-M., Zhong, H., Liu, Y.-M., Tang, N., Zhu, L.-P., et al. (2017). TRPC1 stimulates calcium-sensing receptor-induced store-operated $\mathrm{Ca} 2+$ entry and nitric oxide production in endothelial cells. Mol. Med. Rep. 16, 4613-4619. doi: 10.3892/mmr.2017.7164

Ramsey, I. S., Delling, M., and Clapham, D. E. (2006). An introduction to TRP channels. Annu. Rev. Physiol. 68, 619-647. doi: 10.1146/annurev.physiol.68. 040204.100431

Reading, S. A., Earley, S., Waldron, B. J., Welsh, D. G., and Brayden, J. E. (2005). TRPC3 mediates pyrimidine receptor-induced depolarization of cerebral arteries. Am. J. Physiol. Circ. Physiol. 288, H2055-H2061. doi: 10.1152/ajpheart. 00861.2004

Ren, X., Ren, L., Wei, Q., Shao, H., Chen, L., and Liu, N. (2017). Advanced glycation end-products decreases expression of endothelial nitric oxide synthase through oxidative stress in human coronary artery endothelial cells. Cardiovasc. Diabetol. 16:52. doi: 10.1186/s12933-017-0531-9

Rittig, K., Staib, K., Machann, J., Böttcher, M., Peter, A., Schick, F., et al. (2008). Perivascular fatty tissue at the brachial artery is linked to insulin resistance but not to local endothelial dysfunction. Diabetologia 51, 2093-2099. doi: 10.1007/ s00125-008-1128-3

Rosado, J. A., Brownlow, S. L., and Sage, S. O. (2002). Endogenously expressed trp 1 is involved in store-mediated Ca $2+$ entry by conformational coupling in human platelets. J. Biol. Chem. 277, 42157-42163. doi: 10.1074/jbc. M207320200

Ru, X., Zheng, C., Zhao, Q., Lan, H.-Y., Huang, Y., Wan, S., et al. (2015). Transient receptor potential channel $\mathrm{M} 2$ contributes to neointimal hyperplasia in vascular walls. Biochim. Biophys. Acta 1852, 1360-1371. doi: 10.1016/j.bbadis.2015. 03.014

Ryder, J. R., Northrop, E., Rudser, K. D., Kelly, A. S., Gao, Z., Khoury, P. R., et al. (2020). Accelerated early vascular aging among adolescents with obesity and/or type 2 diabetes mellitus. J. Am. Heart Assoc. 9:e014891. doi: 10.1161/JAHA.119. 014891

Salcedo, A., Garijo, J., Monge, L., Fernández, N., Luis García-Villalón, A., Sánchez Turrión, V., et al. (2007). Apelin effects in human splanchnic arteries. role of nitric oxide and prostanoids. Regul. Pept. 144, 50-55. doi: 10.1016/j.regpep. 2007.06.005

Samanta, A., Hughes, T. E. T., and Moiseenkova-Bell, V. Y. (2018). Transient receptor potential (TRP) channels. Subcell. Biochem. 87, 141-165. doi: 10.1007/ 978-981-10-7757-9_6

Samie, M., Wang, X., Zhang, X., Goschka, A., Li, X., Cheng, X., et al. (2013). A TRP channel in the lysosome regulates large particle phagocytosis via focal exocytosis. Dev. Cell 26, 511-524. doi: 10.1016/j.devcel.2013.08.003

Samie, M. A., Grimm, C., Evans, J. A., Curcio-Morelli, C., Heller, S., Slaugenhaupt, S. A., et al. (2009). The tissue-specific expression of TRPML2 (MCOLN-2) gene is influenced by the presence of TRPML1. Pflügers Arch. 459, 79-91. doi: 10.1007/s00424-009-0716-5

Sano, Y., Inamura, K., Miyake, A., Mochizuki, S., Yokoi, H., Matsushime, H., et al. (2001). Immunocyte Ca2+ influx system mediated by LTRPC2. Science 293, 1327-1330. doi: 10.1126/science. 1062473

Saxton, S. N., Clark, B. J., Withers, S. B., Eringa, E. C., and Heagerty, A. M. (2019). Mechanistic links between obesity, diabetes, and blood pressure: role of perivascular adipose tissue. Physiol. Rev. 99, 1701-1763. doi: 10.1152/physrev. 00034.2018

Schieber, M., and Chandel, N. S. (2014). ROS function in redox signaling and oxidative stress. Curr. Biol. 24, R453-R462. doi: 10.1016/j.cub.2014.03.034

Schinzari, F., Iantorno, M., Campia, U., Mores, N., Rovella, V., Tesauro, M., et al. (2015). Vasodilator responses and endothelin-dependent vasoconstriction in metabolically healthy obesity and the metabolic syndrome. Am. J. Physiol. Endocrinol. Metab. 309, E787-E792. doi: 10.1152/ajpendo.00278.2015

Schofield, I., Malik, R., Izzard, A., Austin, C., and Heagerty, A. (2002). Vascular structural and functional changes in type 2 diabetes mellitus. Circulation 106, 3037-3043. doi: 10.1161/01.CIR.0000041432.8 0615.A5 
Scotto Rosato, A., Montefusco, S., Soldati, C., Di Paola, S., Capuozzo, A., Monfregola, J., et al. (2019). TRPML1 links lysosomal calcium to autophagosome biogenesis through the activation of the CaMKK $\beta /$ VPS34 pathway. Nat. Commun. 10:5630. doi: 10.1038/s41467-019-13572-w

Sheu, M. L., Chiang, C. K., Tsai, K. S., Ho, F. M., Weng, T. I., Wu, H. Y., et al. (2008). Inhibition of NADPH oxidase-related oxidative stress-triggered signaling by honokiol suppresses high glucose-induced human endothelial cell apoptosis. Free Radic. Biol. Med. 44, 2043-2050. doi: 10.1016/j.freeradbiomed.2008. 03.014

Sheu, M. L., Ho, F. M., Yang, S. R., Chao, K. F., Lin, W. W., Lin-Shiau, S. Y., et al. (2005). High glucose induces human endothelial cell apoptosis through a phosphoinositide 3-kinase-regulated cyclooxygenase-2 pathway. Arterioscler. Thromb. Vasc. Biol. 25, 539-545.

Shi, J., Miralles, F., Birnbaumer, L., Large, W. A., and Albert, A. P. (2016). Store depletion induces G $\alpha$ q-mediated PLC $\beta 1$ activity to stimulate TRPC1 channels in vascular smooth muscle cells. FASEB J. 30, 702-715.

Shin, M., Eraso, C. C., Mu, Y., Gu, C., Yeung, B. H. Y., Kim, L. J., et al. (2019). Leptin induces hypertension acting on transient receptor potential melastatin 7 channel in the carotid body. Circ. Res. 125, 989-1002. doi: 10.1161/ CIRCRESAHA.119.315338

Sierra-Valdez, F., Azumaya, C. M., Romero, L. O., Nakagawa, T., and CorderoMorales, J. F. (2018). Structure-function analyses of the ion channel TRPC3 reveal that its cytoplasmic domain allosterically modulates channel gating. J. Biol. Chem. 293, 16102-16114. doi: 10.1074/jbc.RA118.005066

Silveira, E. A., de Souza Rosa, L. P., de Carvalho Santos, A. S. E. A., de Souza Cardoso, C. K., and Noll, M. (2020). Type 2 diabetes mellitus in class II and III obesity: prevalence, associated factors, and correlation between glycemic parameters and body mass index. Int. J. Environ. Res. Public Health 17:3930. doi: 10.3390/ijerph17113930

Sivitz, W. I., Wayson, S. M., Bayless, M. L., Sinkey, C. A., and Haynes, W. G. (2007). Obesity impairs vascular relaxation in human subjects: hyperglycemia exaggerates adrenergic vasoconstriction. J. Diabetes Complications 21, 149-157. doi: 10.1016/j.jdiacomp.2005.12.003

Smith, G. D., Gunthorpe, M. J., Kelsell, R. E., Hayes, P. D., Reilly, P., Facer, P., et al. (2002). TRPV3 is a temperature-sensitive vanilloid receptor-like protein. Nature 418, 186-190. doi: 10.1038/nature00894

Soboloff, J., Spassova, M., Xu, W., He, L.-P., Cuesta, N., and Gill, D. L. (2005). Role of endogenous TRPC6 channels in Ca2+ signal generation in A7r5 smooth muscle cells. J. Biol. Chem. 280, 39786-39794. doi: 10.1074/jbc.M506064200

Soni, H., Peixoto-Neves, D., Matthews, A. T., and Adebiyi, A. (2017). TRPV4 channels contribute to renal myogenic autoregulation in neonatal pigs. Am. J. Physiol. Physiol. 313, F1136-F1148. doi: 10.1152/ajprenal.00300.2017

Sonkusare, S. K., Bonev, A. D., Ledoux, J., Liedtke, W., Kotlikoff, M. I., Heppner, T. J., et al. (2012). Elementary Ca2+ signals through endothelial TRPV4 channels regulate vascular function. Science 336, 597-601. doi: 10.1126/science. 1216283

Sonmez, A., Yumuk, V., Haymana, C., Demirci, I., Barcin, C., Kıyıcı, S., et al. (2019). Impact of obesity on the metabolic control of type 2 diabetes: results of the turkish nationwide survey of Glycemic and Other Metabolic Parameters of Patients with Diabetes Mellitus (TEMD Obesity Study). Obes. Facts 12, 167-178. doi: 10.1159/000496624

Soyombo, A. A., Tjon-Kon-Sang, S., Rbaibi, Y., Bashllari, E., Bisceglia, J., Muallem, S., et al. (2006). TRP-ML1 regulates lysosomal $\mathrm{pH}$ and Acidic lysosomal lipid hydrolytic activity. J. Biol. Chem. 281, 7294-7301. doi: 10.1074/jbc.M5082 11200

Starkus, J. G., Fleig, A., and Penner, R. (2010). The calcium-permeable non-selective cation channel TRPM2 is modulated by cellular acidification. J. Physiol. 588, 1227-1240. doi: 10.1113/jphysiol.2010. 187476

Steinberg, H. O., Chaker, H., Leaming, R., Johnson, A., Brechtel, G., and Baron, A. D. (1996). Obesity/insulin resistance is associated with endothelial dysfunction: implications for the syndrome of insulin resistance. J. Clin. Invest. 97, 2601-2610. doi: 10.1172/JCI118709

Story, G. M., Peier, A. M., Reeve, A. J., Eid, S. R., Mosbacher, J., Hricik, T. R., et al. (2003). ANKTM1, a TRP-like channel expressed in nociceptive neurons, is activated by cold temperatures. Cell 112, 819-829. doi: 10.1016/S0092-8674(03) 00158-2
Strotmann, R., Harteneck, C., Nunnenmacher, K., Schultz, G., and Plant, T. D. (2000). OTRPC4, a nonselective cation channel that confers sensitivity to extracellular osmolarity. Nat. Cell Biol. 2, 695-702. doi: 10.1038/35036318

Strübing, C., Krapivinsky, G., Krapivinsky, L., and Clapham, D. E. (2003). Formation of Novel TRPC channels by complex subunit interactions in embryonic brain. J. Biol. Chem. 278, 39014-39019. doi: 10.1074/jbc. M306705200

Sukumar, P., Sedo, A., Li, J., Wilson, L. A., O’Regan, D., Lippiat, J. D., et al. (2012). Constitutively active TRPC channels of adipocytes confer a mechanism for sensing dietary fatty acids and regulating adiponectin. Circ. Res. 111, 191-200. doi: 10.1161/CIRCRESAHA.112.270751

Sun, J., Pu, Y., Wang, P., Chen, S., Zhao, Y., Liu, C., et al. (2013). TRPV1mediated UCP2 upregulation ameliorates hyperglycemia-induced endothelial dysfunction. Cardiovasc. Diabetol. 12:69. doi: 10.1186/1475-2840-12-69

Sun, L., Li, H., Tai, L. W., Gu, P., and Cheung, C. W. (2018). Adiponectin regulates thermal nociception in a mouse model of neuropathic pain. Br. J. Anaesth. 120, 1356-1367. doi: 10.1016/j.bja.2018.01.016

Sun, L., Liu, Y.-L., Ye, F., Xie, J.-W., Zeng, J.-W., Qin, L., et al. (2019). Free fatty acid-induced $\mathrm{H} 2 \mathrm{O} 2$ activates TRPM2 to aggravate endothelial insulin resistance via Ca2+-dependent PERK/ATF4/TRB3 cascade in obese mice. Free Radic. Biol. Med. 143, 288-299. doi: 10.1016/j.freeradbiomed.2019.08.018

Sun, L., Yau, H.-Y., Wong, W.-Y., Li, R. A., Huang, Y., and Yao, X. (2012). Role of TRPM2 in H2O2-induced cell apoptosis in endothelial cells. PLoS One 7:e43186. doi: 10.1371/journal.pone.0043186

Sun, M., Goldin, E., Stahl, S., Falardeau, J. L., Kennedy, J. C., Acierno, J. S. Jr., et al. (2000). Mucolipidosis type IV is caused by mutations in a gene encoding a novel transient receptor potential channel. Hum. Mol. Genet. 9, 2471-2478. doi: $10.1093 / \mathrm{hmg} / 9.17 .2471$

Sundivakkam, P. C., Freichel, M., Singh, V., Yuan, J. P., Vogel, S. M., Flockerzi, V., et al. (2012). The Ca2+ sensor stromal interaction molecule 1 (STIM1) is necessary and sufficient for the store-operated $\mathrm{Ca} 2+$ entry function of transient receptor potential canonical (TRPC) 1 and 4 channels in endothelial Cells. Mol. Pharmacol. 81, 510-526. doi: 10.1124/mol.111.074658

Suzuki, M., Mizuno, A., Kodaira, K., and Imai, M. (2003). Impaired pressure sensation in mice lacking TRPV4. J. Biol. Chem. 278, 22664-22668. doi: 10. 1074/jbc.M302561200

Taha, I. M., Abdulla, A. M., and Elimam, H. (2019). Inflammatory markers and control of type 2 diabetes mellitus. Diabetes Metab. Syndr. 13, 800-804. doi: 10.1016/j.dsx.2018.11.061

Tai, K., Hamaide, M.-C., Debaix, H., Gailly, P., Wibo, M., and Morel, N. (2008). Agonist-evoked calcium entry in vascular smooth muscle cells requires IP3 receptor-mediated activation of TRPC1. Eur. J. Pharmacol. 583, 135-147. doi: 10.1016/j.ejphar.2008.01.007

Tajeddine, N., and Gailly, P. (2012). TRPC1 protein channel is major regulator of epidermal growth factor receptor signaling. J. Biol. Chem. 287, 16146-16157. doi: 10.1074/jbc.M112.340034

Thakore, P., Pritchard, H. A. T., Griffin, C. S., Yamasaki, E., Drumm, B. T., Lane, C., et al. (2020). TRPML1 channels initiate Ca $2+$ sparks in vascular smooth muscle cells. Sci. Signal. 13:eaba1015. doi: 10.1126/scisignal.aba1015

Thorneloe, K. S., Cheung, M., Bao, W., Alsaid, H., Lenhard, S., Jian, M.-Y., et al. (2012). An orally active TRPV4 channel blocker prevents and resolves pulmonary edema induced by heart failure. Sci. Transl. Med. 4:159ra148. doi: 10.1126/scitranslmed.3004276

Tiruppathi, C., Freichel, M., Vogel, S. M., Paria, B. C., Mehta, D., Flockerzi, V., et al. (2002). Impairment of Store-Operated Ca 2+ Entry in TRPC4 -/- mice interferes with increase in lung microvascular permeability. Circ. Res. 91, 70-76. doi: 10.1161/01.RES.0000023391.40106.A8

Togashi, K., Hara, Y., Tominaga, T., Higashi, T., Konishi, Y., Mori, Y., et al. (2006). TRPM2 activation by cyclic ADP-ribose at body temperature is involved in insulin secretion. EMBO J. 25, 1804-1815. doi: 10.1038/sj.emboj.7601083

Tominaga, M., Caterina, M. J., Malmberg, A. B., Rosen, T. A., Gilbert, H., Skinner, K., et al. (1998). The cloned capsaicin receptor integrates multiple pain-producing stimuli. Neuron 21, 531-543.

Tóth, A., Boczán, J., Kedei, N., Lizanecz, E., Bagi, Z., Papp, Z., et al. (2005). Expression and distribution of vanilloid receptor 1 (TRPV1) in the adult rat brain. Mol. Brain Res. 135, 162-168. doi: 10.1016/j.molbrainres.2004. 12.003 
Tóth, A., Czikora, Á., Pásztor, E. T., Dienes, B., Bai, P., Csernoch, L., et al. (2014). Vanilloid receptor-1 (TRPV1) expression and function in the vasculature of the rat. J. Histochem. Cytochem. 62, 129-144. doi: 10.1369/0022155413513589

Tsavaler, L., Shapero, M. H., Morkowski, S., and Laus, R. (2001). Trp-p8, a novel prostate-specific gene, is up-regulated in prostate cancer and other malignancies and shares high homology with transient receptor potential calcium channel proteins. Cancer Res. 61, 3760-3769.

van Wijngaarden, R. P. T., Overbeek, J. A., Heintjes, E. M., Schubert, A., Diels, J., Straatman, H., et al. (2017). Relation between different measures of glycemic exposure and microvascular and macrovascular complications in patients with type 2 diabetes mellitus: an observational cohort study. Diabetes Ther. 8, 1097-1109. doi: 10.1007/s13300-017-0301-4

Vazquez, G., Wedel, B. J., Kawasaki, B. T., Bird, G. S. J., and Putney, J. W. (2004). Obligatory role of Src kinase in the signaling mechanism for TRPC3 cation channels. J. Biol. Chem. 279, 40521-40528. doi: 10.1074/jbc.M405280200

Venkatachalam, K., Hofmann, T., and Montell, C. (2006). Lysosomal localization of TRPML3 depends on TRPML2 and the mucolipidosis-associated protein TRPML1. J. Biol. Chem. 281, 17517-17527. doi: 10.1074/jbc.M600807200

Vergarajauregui, S., and Puertollano, R. (2006). Two Di-Leucine motifs regulate trafficking of mucolipin-1 to lysosomes. Traffic 7, 337-353. doi: 10.1111/j.16000854.2006.00387.x

Virdis, A., Duranti, E., Rossi, C., Dell'Agnello, U., Santini, E., Anselmino, M., et al. (2015). Tumour necrosis factor-alpha participates on the endothelin-1/nitric oxide imbalance in small arteries from obese patients: role of perivascular adipose tissue. Eur. Heart J. 36, 784-794. doi: 10.1093/eurheartj/ehu072

Voets, T., Prenen, J., Vriens, J., Watanabe, H., Janssens, A., Wissenbach, U., et al. (2002). Molecular determinants of permeation through the cation channel TRPV4. J. Biol. Chem. 277, 33704-33710. doi: 10.1074/jbc.M204828200

Wang, J., Shimoda, L. A., and Sylvester, J. T. (2004). Capacitative calcium entry and TRPC channel proteins are expressed in rat distal pulmonary arterial smooth muscle. Am. J. Physiol. Cell. Mol. Physiol. 286, L848-L858. doi: 10.1152/ajplung. 00319.2003

Wang, L. H., Luo, M., Wang, Y., Galligan, J. J., and Wang, D. H. (2006). Impaired vasodilation in response to perivascular nerve stimulation in mesenteric arteries of TRPV1-null mutant mice. J. Hypertens. 24, 2399-2408. doi: 10.1097/01.hjh. 0000251900.78051 .56

Wang, P., Xu, T.-Y., Guan, Y.-F., Su, D.-F., Fan, G.-R., and Miao, C.-Y. (2009). Perivascular adipose tissue-derived visfatin is a vascular smooth muscle cell growth factor: role of nicotinamide mononucleotide. Cardiovasc. Res. 81, 370380. doi: $10.1093 / \mathrm{cvr} / \mathrm{cvn} 288$

Wang, Z., Yang, J., Qi, J., Jin, Y., and Tong, L. (2020). Activation of NADPH/ROS pathway contributes to angiogenesis through JNK signaling in brain endothelial cells. Microvasc. Res. 131, 104012. doi: 10.1016/j.mvr.2020.104012

Watanabe, H., Davis, J. B., Smart, D., Jerman, J. C., Smith, G. D., Hayes, P., et al. (2002a). Activation of TRPV4 channels (hVRL-2/mTRP12) by phorbol derivatives. J. Biol. Chem. 277, 13569-13577. doi: 10.1074/jbc.M200062200

Watanabe, H., Vriens, J., Suh, S. H., Benham, C. D., Droogmans, G., and Nilius, B. (2002b). Heat-evoked activation of TRPV4 Channels in a HEK293 cell expression system and in native mouse aorta endothelial cells. J. Biol. Chem. 277, 47044-47051. doi: 10.1074/jbc.M208277200

Watanabe, H., Vriens, J., Prenen, J., Droogmans, G., Voets, T., and Nilius, B. (2003). Anandamide and arachidonic acid use epoxyeicosatrienoic acids to activate TRPV4 channels. Nature 424, 434-438. doi: 10.1038/nature01807

Wei, J., Ching, L.-C., Zhao, J.-F., Shyue, S.-K., Lee, H.-F., Kou, Y. R., et al. (2013). Essential role of transient receptor potential vanilloid type 1 in evodiaminemediated protection against atherosclerosis. Acta Physiol. 207, 299-307. doi: 10.1111/apha.12005

Weil, B. R., Westby, C. M., Van Guilder, G. P., Greiner, J. J., Stauffer, B. L., and DeSouza, C. A. (2011). Enhanced endothelin-1 system activity with overweight and obesity. Am. J. Physiol. Circ. Physiol. 301, H689-H695. doi: 10.1152/ ajpheart.00206.2011

Wes, P. D., Chevesich, J., Jeromin, A., Rosenberg, C., Stetten, G., and Montell, C. (1995). TRPC1, a human homolog of a Drosophila store-operated channel. Proc. Natl. Acad. Sci. U.S.A. 92, 9652-9656. doi: 10.1073/pnas.92.21.9652

Wölfle, S. E., Navarro-Gonzalez, M. F., Grayson, T. H., Stricker, C., and Hill, C. E. (2010). Involvement of nonselective cation channels in the depolarisation initiating vasomotion. Clin. Exp. Pharmacol. Physiol. 37, 536-543. doi: 10.1111/ j.1440-1681.2010.05350.x
World Health Organization (2019). Classification of Diabetes Mellitus. Geneva: World Health Organization.

World Health Organization (2020). World Health Statistics 2020: Monitoring Health for the SDGs, Sustainable Development Goals. Geneva: World Health Organization.

Xie, Z., Su, W., Guo, Z., Pang, H., Post, S., and Gong, M. (2006). Up-regulation of CPI-17 phosphorylation in diabetic vasculature and high glucose cultured vascular smooth muscle cells. Cardiovasc. Res. 69, 491-501. doi: 10.1016/j. cardiores.2005.11.002

Xu, B., Chibber, R., Ruggiero, D., Kohner, E., Ritter, J., and Ferro, A. (2003). Impairment of vascular endothelial nitric oxide synthase activity by advanced glycation end products. FASEB J. 17, 1289-1291. doi: 10.1096/fj.02-0490fje

Xu, H., Delling, M., Li, L., Dong, X., and Clapham, D. E. (2007). Activating mutation in a mucolipin transient receptor potential channel leads to melanocyte loss in varitint-waddler mice. Proc. Natl. Acad. Sci. U.S.A. 104, 18321-18326. doi: 10.1073/pnas.0709096104

Xu, H., Zhao, H., Tian, W., Yoshida, K., Roullet, J.-B., and Cohen, D. M. (2003). Regulation of a transient receptor potential (TRP) channel by tyrosine phosphorylation. J. Biol. Chem. 278, 11520-11527. doi: 10.1074/jbc. M211061200

$\mathrm{Xu}, \mathrm{S}$., and Beech, D. J. (2001). TrpC1 is a membrane-spanning subunit of storeoperated $\mathrm{Ca} 2+$ channels in native vascular smooth muscle cells. Circ. Res. 88, 84-87. doi: 10.1161/01.RES.88.1.84

Xu, S.-Z., Boulay, G., Flemming, R., and Beech, D. J. (2006). E3-targeted antiTRPC5 antibody inhibits store-operated calcium entry in freshly isolated pial arterioles. Am. J. Physiol. Circ. Physiol. 291, H2653-H2659. doi: 10.1152/ ajpheart.00495.2006

Yamawaki, H., Hara, N., Okada, M., and Hara, Y. (2009). Visfatin causes endothelium-dependent relaxation in isolated blood vessels. Biochem. Biophys. Res. Commun. 383, 503-508. doi: 10.1016/j.bbrc.2009.04.074

Yamawaki, H., Tsubaki, N., Mukohda, M., Okada, M., and Hara, Y. (2010). Omentin, a novel adipokine, induces vasodilation in rat isolated blood vessels. Biochem. Biophys. Res. Commun. 393, 668-672. doi: 10.1016/j.bbrc.2010. 02.053

Yang, D., Luo, Z., Ma, S., Wong, W. T., Ma, L., Zhong, J., et al. (2010). Activation of TRPV1 by dietary capsaicin improves endothelium-dependent vasorelaxation and prevents hypertension. Cell Metab. 12, 130-141. doi: 10.1016/j.cmet.2010. 05.015

Yang, X.-R., Lin, A. H. Y., Hughes, J. M., Flavahan, N. A., Cao, Y.-N., Liedtke, W., et al. (2012). Upregulation of osmo-mechanosensitive TRPV4 channel facilitates chronic hypoxia-induced myogenic tone and pulmonary hypertension. Am. J. Physiol. Cell. Mol. Physiol. 302, L555-L568. doi: 10.1152/ ajplung.00005.2011

Yang, X.-R., Lin, M.-J., McIntosh, L. S., and Sham, J. S. K. (2006). Functional expression of transient receptor potential melastatin- and vanilloid-related channels in pulmonary arterial and aortic smooth muscle. Am. J. Physiol. Lung Cell. Mol. Physiol. 290, L1267-L1276. doi: 10.1152/ajplung.00515.2005

Yao, L., Bhatta, A., Xu, Z., Chen, J., Toque, H. A., Chen, Y., et al. (2017). Obesity-induced vascular inflammation involves elevated arginase activity. Am. J. Physiol. Integr. Comp. Physiol. 313, R560-R571. doi: 10.1152/ajpregu.00529. 2016

Yip, H., Chan, W.-Y., Leung, P.-C., Kwan, H.-Y., Liu, C., Huang, Y., et al. (2004). Expression of TRPC homologs in endothelial cells and smooth muscle layers of human arteries. Histochem. Cell Biol. 122, 553-561. doi: 10.1007/s00418-0040720-y

Yu, P., Xue, X., Zhang, J., Hu, X., Wu, Y., Jiang, L.-H., et al. (2017). Identification of the ADPR binding pocket in the NUDT9 homology domain of TRPM2. J. Gen. Physiol. 149, 219-235. doi: 10.1085/jgp.201611675

Yu, Q., Wang, D., Wen, X., Tang, X., Qi, D., He, J., et al. (2020). Adipose-derived exosomes protect the pulmonary endothelial barrier in ventilator-induced lung injury by inhibiting the TRPV4/Ca $2+$ signaling pathway. Am. J. Physiol. Cell. Mol. Physiol. 318, L723-L741. doi: 10.1152/ajplung.00255.2019

Yu, W., Hill, W. G., Apodaca, G., and Zeidel, M. L. (2011). Expression and distribution of transient receptor potential (TRP) channels in bladder epithelium. Am. J. Physiol. Physiol. 300, F49-F59. doi: 10.1152/ajprenal.00349. 2010

Yu, Y., Fantozzi, I., Remillard, C. V., Landsberg, J. W., Kunichika, N., Platoshyn, O., et al. (2004). Enhanced expression of transient receptor potential channels 
in idiopathic pulmonary arterial hypertension. Proc. Natl. Acad. Sci. U.S.A. 101, 13861-13866. doi: 10.1073/pnas.0405908101

Zeevi, D. A., Lev, S., Frumkin, A., Minke, B., and Bach, G. (2010). Heteromultimeric TRPML channel assemblies play a crucial role in the regulation of cell viability models and starvation-induced autophagy. J. Cell Sci. 123, 3112-3124. doi: $10.1242 /$ jcs. 067330

Zhang, C., Park, Y., Picchi, A., and Potter, B. J. (2008). Maturation-induces endothelial dysfunction via vascular inflammation in diabetic mice. Basic Res. Cardiol. 103, 407-416. doi: 10.1007/s00395-008-0725-0

Zhang, F., Jin, S., Yi, F., and Li, P.-L. (2009). TRP-ML1 functions as a lysosomal NAADP-sensitive Ca2+ release channel in coronary arterial myocytes. J. Cell. Mol. Med. 13, 3174-3185. doi: 10.1111/j.1582-4934.2008.00486.x

Zhang, F., and Li, P.-L. (2007). Reconstitution and characterization of a nicotinic acid adenine dinucleotide phosphate (NAADP)-sensitive $\mathrm{Ca} 2+$ release channel from liver lysosomes of rats. J. Biol. Chem. 282, 25259-25269. doi: 10.1074/jbc. M701614200

Zhang, F., Zhang, G., Zhang, A. Y., Koeberl, M. J., Wallander, E., and Li, P.-L. (2006). Production of NAADP and its role in Ca2+ mobilization associated with lysosomes in coronary arterial myocytes. Am. J. Physiol. Circ. Physiol. 291, H274-H282. doi: 10.1152/ajpheart.01064.2005

Zhang, L., Papadopoulos, P., and Hamel, E. (2013). Endothelial TRPV4 channels mediate dilation of cerebral arteries: impairment and recovery in cerebrovascular pathologies related to Alzheimer's disease. Br. J. Pharmacol. 170, 661-670. doi: 10.1111/bph.12315

Zhang, L. L., Yan Liu, D., Ma, L. Q., Luo, Z. D., Cao, T. B., Zhong, J., et al. (2007). Activation of transient receptor potential vanilloid type-1 channel prevents adipogenesis and obesity. Circ. Res. 100, 1063-1070. doi: 10.1161/01. RES.0000262653.84850.8b

Zhang, Q., Cao, Y., Luo, Q., Wang, P., Shi, P., Song, C., et al. (2018). The transient receptor potential vanilloid-3 regulates hypoxia-mediated pulmonary artery smooth muscle cells proliferation via PI3K/AKT signaling pathway. Cell Prolif. 51:e12436. doi: 10.1111/cpr.12436
Zhang, Y., Chen, Q., Sun, Z., Han, J., Wang, L., and Zheng, L. (2015). Impaired capsaicin-induced relaxation in diabetic mesenteric arteries. J. Diabetes Complications 29, 747-754. doi: 10.1016/j.jdiacomp.2015. 05.005

Zhao, J.-F., Shyue, S.-K., Kou, Y. R., Lu, T.-M., and Lee, T.-S. (2016). Transient receptor potential Ankyrin 1 channel involved in atherosclerosis and macrophage-foam cell formation. Int. J. Biol. Sci. 12, 812-823. doi: 10.7150/ijbs. 15229

Zhao, Q., Yang, J., Liu, B., Huang, F., and Li, Y. (2019). Exosomes derived from mangiferin-stimulated perivascular adipose tissue ameliorate endothelial dysfunction. Mol. Med. Rep. 19, 4797-4805. doi: 10.3892/mmr.2019. 10127

Zhou, Y., Zhang, M.-J., Li, B.-H., Chen, L., Pi, Y., Yin, Y.-W., et al. (2016). PPAR $\gamma$ inhibits VSMC proliferation and migration via attenuating oxidative stress through upregulating UCP2. PLoS One 11:e0154720. doi: 10.1371/journal.pone. 0154720

Zygmunt, P. M., Petersson, J., Andersson, D. A., Chuang, H., Sørgård, M., Di Marzo, V., et al. (1999). Vanilloid receptors on sensory nerves mediate the vasodilator action of anandamide. Nature 400, 452-457. doi: 10.1038/ 22761

Conflict of Interest: The authors declare that the research was conducted in the absence of any commercial or financial relationships that could be construed as a potential conflict of interest.

Copyright $\odot 2021$ Moraes, Webb and Silva. This is an open-access article distributed under the terms of the Creative Commons Attribution License (CC BY). The use, distribution or reproduction in other forums is permitted, provided the original author(s) and the copyright owner(s) are credited and that the original publication in this journal is cited, in accordance with accepted academic practice. No use, distribution or reproduction is permitted which does not comply with these terms. 